\title{
GÖZDEN IRAK, GÖNÜLDEN IRAK: POLİTİK BİR AYGIT OLARAK EKRAN DIŞI UZAY-ZAMAN
}

\author{
Mehmet Köprü
}

\begin{abstract}
Öz
Tekniği gizlemeye dayalı devamlılık kurgusunun norm biçem kabul edildiği ana akım sinemada saklamak, olağan bir edimdir. Anlatı sineması, aracısız öykü aktarımı yanılsamasını sürdürebilmek için öncelikle kendi işleyişini gizlemek zorundadır. O nedenle, ideoloji ve saklama ilişkisi de genellikle bu perspektiften, yani aracın kendi işleyişinin gizlenmesi üzerinden yapılmıştır. Oysa bazı öykü unsurlarının görünür uzay-zamanın dışında tutulmaya çalışılması da en az fantazmagorik çabalar kadar ideolojiktir. Diegetik evrene ait olan kimi kişiler ya da olaylar, bazen aleni politik amaçlarla, bazen de toplumsal psişeyle bağlantılı kanıksanmış kültürel eğilimlerle çerçeve dışında tutulmaktadırlar. Ötekiyle kurulacak empatinin engellenmesi, kolektif suçların örtülmesi ya da gerçek muktedirin gizlenmesi gibi kasıtlı girişimler filmlerde genellikle alan dışı üzerinden çalıştırılır. Böylece burası, biçimsel (anlatı dünyasını şekillendirmek) ve retorik (merak, endişe, beklenti ve korku yaratmak) işlevlerine ek olarak kültür ve ideoloji ile bağlantılı yeni görevlerle donatılır. Diğer taraftan, ekran dışının görünmez varlığı, sinemanın kullandığı tüm temsil kodlarını kuşatan ideolojinin dışına çıkmak için de ideal bir zemin sunmaktadır. Bu yönleriyle düşünüldüğünde ekran dışı uzay-zaman, bir taraftan egemen düşünceye hizmet ederken diğer taraftan ondan kaçışın yolunu da açabilen politik bir araç olabilmektedir. Burası, sinema ve ideoloji ilişkisini yeni bir bakışla değerlendirmek için farklı olanaklar sunmaktadır. Bu olanaklar çevresinde şekillenen çalışmada, filmlerdeki göstermeme edimlerinin arkasındaki politik ve toplumsal motivasyonlar, hem normu temsil eden ana akım yapımlarla, hem de bu normları yapı bozumuna uğratan alternatif örneklerle ele alınacaktır. Böylece filmlerin, sadece gösterdikleriyle değil, sakladıklarıyla da politik bir işlevselliğe sahip olduğuna dikkat çekilecektir.
\end{abstract}

Anahtar Sözcükler: Ekran dışı, saklamanın ideolojisi, dışardaki öteki, görünmeyen muktedir. 


\title{
OUT OF SIGHT AND OUT OF HEART: OFF-SCREEN SPACE- TIME AS A POLITICAL DEVICE
}

\begin{abstract}
In mainstream cinema, in which the technique of concealment-based continuity is the norm, hiding is a customary act. Narrative cinema has to hide its functioning to maintain the illusion of direct storytelling. But the act of concealment also has an ideological dimension, and the "off-screen" is often as ideologically laden as the visible space-time in a film. Some individuals or events belonging to the diegetic universe are kept off-screen because of specific political purposes or cultural tendencies associated with the social psyche. In films, deliberate efforts to prevent empathy with the other, to cover up collective crimes, and to conceal the real power often operate through the off-screen. Thus, in addition to its formal functions (shaping the narrative world) and rhetorical functions (creating curiosity, suspense, expectation, and fear), the off-screen is equipped with new tasks connected with culture and ideology. At the same time, the invisible presence of the off-screen space provides an ideal basis for going beyond the ideology that encompasses all the representational codes used by cinema. Considering these aspects, off-screen space-time can be a political tool that can mediate dominant thinking, but it can also be the means for escaping from it. This space offers different possibilities to discuss the relationship between cinema and ideology from a new perspective. Focusing on these possibilities, this study discusses the political and social motivations behind "not showing" in films, including both mainstream productions representing the norm and alternative examples that disrupt these norms, to argue that films have a political function in terms not only of what they show but also of what they hide.
\end{abstract}

Keywords: Off-screen, ideology of hiding, the other outside, invisible ruler. 


\section{Giriş $^{1}$}

Michelangelo Antonioni'nin Batan Güneş'inde (L'eclisse, 1962), filmin temel anlatısıyla ilgisiz görünmesine rağmen fotografik ve sinematik temsilin olanakları, sınırları ve bu sınırlarla bağlantılı masumiyetleri üzerine düşündüren önemli bir sahne vardır: Öykünün duygusal boşluktaki karakteri Vittoria (Monica Vitti), Kenya'dan henüz dönmüş olan yeni komşusunun evini isteksizce de olsa ziyarete gittiğinde duvardaki Afrika manzaraları ilgisini çeker ve ev sahibine bunlarla ilgili bir şeyler sorar. Ev sahibi kadın, buradaki posterlerden birinin bir süre öncesine kadar kendi yaşadıkları yere ait olduğunu söyleyince Vittoria söz konusu çiftliğin yerini öğrenmek amacıyla poster üzerinde rastgele bir yeri işaret ederek "burası mı?" diye sorar. Komşusu yarı İngilizce yarı İtalyanca bir üslupla "solda" diye cevap verir ve fotoğrafın dışında bir alan işaret edilene kadar onu sola yönlendirir (Görsel 1). Çünkü kadının bahsettiği ve Vittoria'nın görmek istediği çiftlik aslında kadrajın dışındadır.

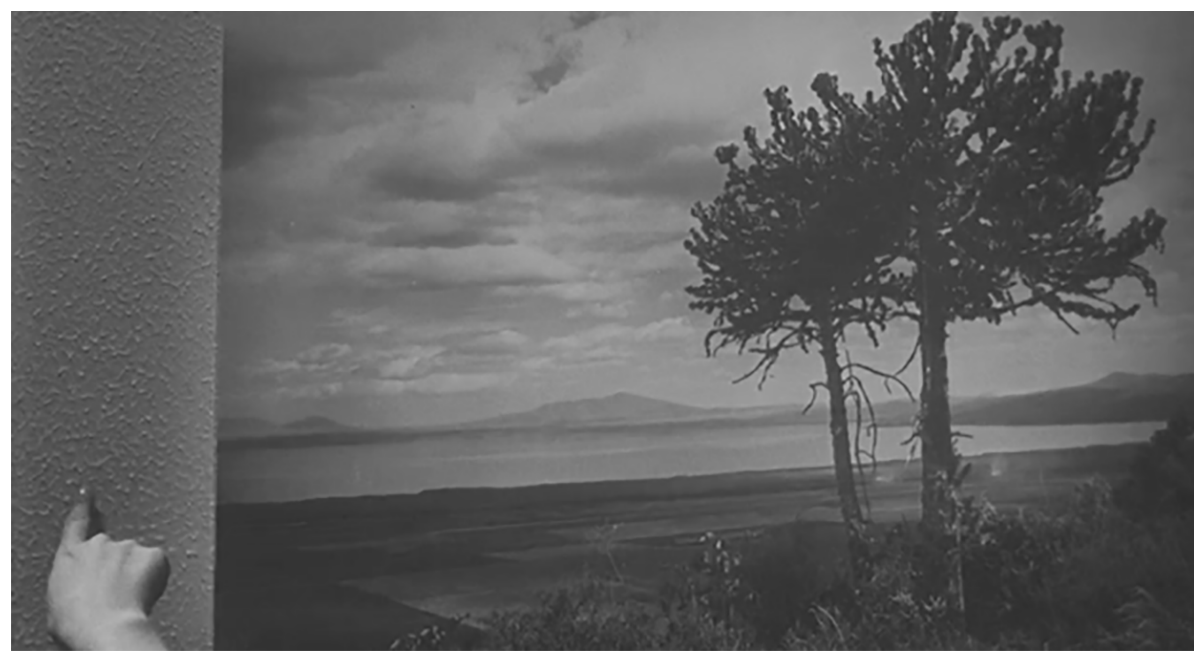

Görsel 1: Batan Güneş'ten ekran görüntüsü.

$\mathrm{Bu}$ sahne, öykünün kendi bağlamı içerisinde yorumlanabileceği (yaşamında bazı belirsizlikler olan Vittoria'nın aradığı şey başka bir yerdedir) gibi, görünenle görünmeyen ya da görüntü ile gerçek arasındaki ilişkiyi sorgulamak için de uygun bir zemin sağlamaktadır. İmgesel ara-

1 Bu çalışma, yazarın Ankara Üniversitesi Sosyal Bilimler Enstitüsü'nde tamamladığı Görünmeyen Sinema: Eksilti ve Alan Dışının Film Anlatısı ve Estetiğindeki Yeri (2018) adlı doktora tezinden üretilmiştir. 
ca ve fotografik temsile dair bu tür öz-düşünümsel sorgulamaların bolca yapıldığı Cinayeti Gördüm (Blow-Up, 1966) gibi başka Antonioni filmleri de göz önünde bulundurulursa, aynı şeyin bu kez ekran dışı uzay-zaman ${ }^{2}$ üzerinden gerçekleştiğini düşünmek mümkündür. Ancak söz konusu Afrika olunca, konu bu kez ontolojik bir "görüntünün hakikati" meselesinden uzaklaşıp, politik bir "sunulanın doğruluğu" tartışmasına doğru kaymaktadır. Çünkü burası, Antonioni'nin odaklandığı ve çözümlemeye çalıştığı modern batılı birey için bir "öteki mekânıdır". Nitekim yönetmen, Yolcu'da da (Professione: Reporter, 1975) kameranın gördüğü/gösterdiği ile görmediği/göstermediği mekanlar üzerinden benzer politik sorgulamalar yaparken yine Afrika'yı merkezine almıştır. Ölmüş olduğu düşünülen gazeteci arkadaşı David Locke'un (Jack Nicholson) bir belgeselini yapmak isteyen yapımcı Knight (Ian Hendry), onun Kuzey Afrika'da çektiği ham görüntüleri David'in karısı Rachel'e (Jenny Runacre) izlettirirken bu tür

2 Filmler sadece çerçeve kenarlarını kullanarak dışarıda bırakmazlar. Henüz senaryo aşamasında, olay örgüsü tasarlanırken öykü evrenine ait bazı unsurlar çıkartılmaya başlanır. Bu bağlamda, eksiltme de özünde bir dışarıda bırakma işlemidir ve çekim sırasında çerçeve yaratılırken gerçekleştirilen dışarıda bırakmayla aynı amaca hizmet eder. Ama ne var ki, daha çok stilistik çalışmaların alanında kalan ekran dışı, uzamsal bir işlem olarak görülürken, edebiyat çalışmalarının daha fazla ağırlık verdiği eksiltme salt anlatı zamanıyla ilgili bir edim olarak kabul edilmiştir. Bu yaklaşım, dışarıda bırakma edimini bir bütün olarak değerlendirmeyi engellemesinin yanında çok temel bir fizik kuralıyla da çelişir. Ekran dışı ve eksiltme ayrımı, zaten hep tartışılagelen ama Albert Einstein'ın geliştirdiği genel görelilik kuramından sonra iyice anlamsızlaşan zaman ve uzay ayrımına dayanır. Bu nedenle, çalışmaya kaynaklık eden tez çalışmasında, hem çerçevenin belirlediği sınırlarla hem de anlatı zamanına ait düzenlemelerle dışarıda bırakılan öykü unsurları tek bir kavram altında birleştirilmiştir. "Tümleyen kronotop" ifadesi, romanlardaki uzay-zaman yapılanmalarını anlamak için Mikhail Bakhtin'in fizikten ilham alarak ortaya sürdüğü kronotop kavramının, küme matematiğinde, belirli bir evrensel kümeye ait olmasına rağmen onun altındaki daha küçük bir kümenin kapsamadığı bileşenleri tanımlamak için kullanılan "tümleyen" kavramının birleştirilmesiyle ortaya çıkmıştır. Böylece, hem zaman ve uzamın ayrı ayrı değerlendirilmesinin doğurduğu mantık hatası çözülmüş, hem de dışarıda bırakma işlemi araçtan bağımsız olarak ele alınabilmiştir. Ancak burada, uzun bir kavramsal tartışmaya girmek için yeterli alan olmadığından tümleyen kronotop yerine, yine ekran dışı mekân veya alan dışı uzam gibi daha alışıldık olunan ifadeler kullanılmıştır. Ama yine de, hem fiziksel bir gerçeği hem de olay örgüsü üzerinden yapılan dışarıda bırakmaları göz ardı etmemek için uzay-zaman ifadesine de sıklıkla başvurulmuştur. O nedenle, metin içerisinde karşılaşılacak olan alan dışı uzay-zaman, ekran dışı uzam, çerçeve dışı mekân vb. gibi farklı kavramlaştırmalar aslında tek bir şeye, diegetik evrene ait olmasına rağmen gösterilemeyen anlatı unsurlarına, araçtan (kadraj ve eksiltme) bağımsız bir şekilde gönderme yapmak için kullanılmıştır. 
sorgulamaların da önünü açmış olur. Örneğin bunlardan birinde Afrikalı bir devlet adamı, kadrajı tamamen işgal etmenin verdiği güvenle ülkesine dair çarpıtılmış bilgiler aktarmaktadır. Bu çekimin yapıldığı sırada David'in yanında olan Rachel, şimdi moviolada görüntüleri izlerken o anları yeniden hatırlar ve bu vesileyle belgesel kamerasının gör(e)mediği çevre görüntüler filme yansır. Devlet adamının yaşadığı yere ait olan bu görüntülerin herhangi bir çarpıcılığı olmasa da, çekimden sonra Rachel ve David'in haberin sunumuna dair yaptıkları sohbet ve daha sonraki bölümlerde görülecek olan şok edici bir idam sahnesi, sadece gazetecilik ya da belgeselcilik etiğiyle değil, hareketli görüntülerin gerçeği ne dereceye kadar tarafsız temsil edebileceğiyle ilgili eski soruları da yeniden gündeme getirir. Bu temsiliyet ve dürüstlük meselesiyle ilgili düşünümsellik, incelenen başka bir ham görüntüde kendisini daha net belli eder. Bu film parçasında, bir kabile büyücüsüyle (James Campbell) röportaj yapmaya çalışan David'in "soru soran" sesi alan dişından gelmektedir. Ancak bir dönem Avrupa'nın farklı yerlerinde de yaşadığı için onları gayet iyi tanıyan bilge büyücü, kamerayı David'e çevirerek sorularını bu şekilde sormasını ister. Kendisi hep kameranın arkasındaki güvenli alanda kalırken egzotik yerlerin ya da savaş bölgelerinin insanlarını bakışın malzemesi yapmaktan çekinmemiş olan David'in yüz ifadesi, bu yeni durum karşısındaki şaşkınlığını ve paniğini yansıtmaktadır. Ama bu sadece her zaman kameranın arkasında duran bir gazetecinin bir anda görüntüye girmiş olmasının şaşkınlığı değildir. Bu, aynı zamanda, kendisini sürekli dışarıdaki "ilkel" üzerinden "uygar" olarak konumlandırmaya çalışan batılı bakışın da bir eleştirisidir. Çünkü David gibi gazetecilerin ya da belgeselcilerin kamerası, bir yönüyle, batılı gözün "yaban" diyarlardaki temsilcileridir de.

$\mathrm{Bu}$ göndermeler, kolonyalizmin meşrulaştırılmasından Edward W. Said'in oryantalizm eleştirisine kadar uzanan çok farklı bağlantıları akla getirmektedir. Ama söz konusu sahnelerdeki farklı okumaları sinema açısından asıl önemli hale getiren, seyircinin bakışından saklanan uzay-zamanların; anlatısal ya da dramaturjik işlevlerinin yanında, ideolojik açıdan da tartışmaya açık olduklarını göstermesidir. Antonioni bu sahnelerde bize, filmlerin öykü evrenleri inşa edilirken zorunlu olarak ortaya çıkan ve genellikle sinematik anlatıma kattıkları retorik faydalarla tartışılan çerçeve dişının, bu biçimsel masumiyetin ötesinde de misyonlara sahip olabileceğini hatırlatmaktadır. Bu hatırlatmanın verdiği ilhamdan hareketle, Mikhail Bakhtin'in roman özelinde yaptığını sine- 
maya taşımayı deneyerek ve bunu alan dışı kullanımlarına uygulayarak; "soyut bir 'biçimsel' yaklaşım ile aynı ölçüde soyut 'ideolojik' yaklaşım arasındaki kopukluğu" (2001, s. 33) gidermeye çalışabiliriz.

O nedenle burada, Noël Burch'ün biçimsel sinıflandırmasına ${ }^{3}$ benzer teknik değerlendirmelerden ziyade, Pascal Bonitzer'in "Kör Alan"ına benzer spekülatif ve çok yönlü okumalara daha fazla ağırlık verilecektir. Filmleri, ideolojik okumaların, kültürel çözümlemelerin veya ekonomi-politik bakışın ışığında ele alan Jean-Louis Baudry, Jean-Luc Comolli, Jean Narboni, Robert Kolker, Laura Mulvey, Michael Ryan, Douglas Kellner ve Mike Wayne gibi isimlerin çalışmalarına yine bu bağlamda göz atılacaktır. Konunun; toplumsal ve bireysel bilinçaltını, roman sanatını, muktedirlerin gözetleme ve gizlenme politikalarını, özne inşasını, temsil stratejilerini ve seyirci beklentilerini ilgilendiren başka yönleri de olduğu için Theodor Adorno'dan Slavoj Žižek'e uzanan bir yelpazede eleştirel teori, toplumbilim, psikanaliz, edebiyat çalışmaları ve iktidar eleştirisi gibi farklı alanlardan da yeri geldiğince faydalanılacaktır. Ama yine de, filmlerin "göstermeme" stratejilerinin arkasındaki ideolojik mekanizmaları anlama yönündeki en büyük destek yine filmlerden gelmektedir. Çünkü, belirli bir medyuma ait normların en etkili yapı bozumu ve eleştirisi, yine aynı aracın olanaklarıyla yapılmaktadır. Bu bağlamda, Michael Haneke, Michelangelo Antonioni veya Stanley Kubrick gibi ana akım dışı sanatçıların eserlerindeki ezber bozucu çerçeve dışı kullanımları, geleneksel devamlılık kurgusuna ait uzlaşımların en tutucu ya da en ideal temsilcileri olan John Ford veya Steven Spielberg gibi yönetmenlerin filmlerindeki gösterilmeyen uzay-zamanların politik masumiyetlerini değerlendirmede kıstas işlevi göreceklerdir. Böylece ana akıma ait bilindik ve tipik örnekler aşağıdaki tartışmaların nesnesi olurken, alternatif sinemaya ait filmler büyük oranda çözümün bir parçası haline gelmişlerdir. Ama filmlerin merkezde olduğu bu meselelere geçilmeden önce, sinematik imgenin de kaynağı olan mekanik ve fotografik bakışın tarafsızlığıyla ve ideolojik olmasıyla ilgili eski tartışmaları kısaca da olsa hatırlamak faydalı olabilir.

3 Theory of Film Practice isimli eserinde çerçeve dışına özel bir başlık ayıran Burch'a göre filmlerde, dördü çerçeve kenarlarının dışında, birisi kameranın arkasında ve birisi de önünde olmak üzere toplam altı farklı ekran dışı bölüm vardır (1983: s. 17). 


\section{Göstermenin ve Saklamanın İdeolojisi}

Terry Eagleton İdeoloji isimli çalışmasında, kavramın (bazıları birbiriyle çelişen) 16 farklı tanımını yapar. Bunlardan "belirli bir toplumsal grup veya sınıfa ait fikirler kümesi" (1996, s. 18) şeklindeki en genel olanı Marksizmin, "bir insanin ya da bir toplumsal grubun zihninde egemen olan fikirler, tasarımlar sistemi" (Althusser, 1994, s. 47) olarak özetlenebilecek genel ideoloji anlayışılla da uyumludur. Ancak Louis Althusser'in tanımındaki "egemen" sıfatı, klasik Marksizmin kavrama bakışının olumsuzluğunu da yansıtmaktadır. ${ }^{4}$ Çünkü fikirlerin ya da düşüncelerin başka fikirler üzerinde egemenlik kurması, diyalektik düşünceyi sekteye uğratarak yanlış bilinçlenmenin, köreltici ön yargıların, irrasyonalitenin ve öznenin iktidar sahipleri tarafindan kontrol edilebilmesinin de önünü açar. Bu yönüyle ideoloji, "Lacan'ın "büyük Öteki" dediği şey, sanal simgesel düzen, gerçekliği bizim için yapılandıran şebeke" (Žižek, 2014, s. 312) ile de neredeyse örtüşmektedir. Zaten Žižek'in başka bir yerde de söylediği gibi "öznenin kendi toplumsal-simgesel ağını kuran" şey ideolojik söylemdir (2011, s. 32). Bu nedenle ideolojinin kendisi ya da yansımaları kişiler arası ilişkilerin, toplumsal yaşamın ve kültürel dünyanın her alanında aranabilir.

Günümüz dünyasının en önemli kültürel aracı olmasının yanında, kullandığı dil itibariyle kültüre ait nerdeyse tüm kod sistemlerini içerisinde barındıran sinemayı da ideolojinin bu kapsayıcılığından bağımsız düşünmek olanaksızdır. Filmler, barındırdıkları dilsel, kültürel ve estetik kodlar sayesinde ideolojiyle sürekli etkileşim halindedir: Herhangi bir karakter için o değil de bu kıyafet tercih edildiğinde, kamera o açıdan değil de bu açıdan çekim yaptığında ya da en önemlisi, çekmek için uzamın o parçası değil de bu parçası seçildiğinde ideoloji çoğu kez devrededir. Buradaki seçme işleminin aracın kısıtlarından kaynaklanan bir zorunluluk olması ise bununla ilgili başka bir tartışmayı daha gündeme getirir: Kameranın kendisi sistem içerisindeki kullanıcı faktörler tarafından mı ideolojik hale getirilir yoksa dayatmacı bakışından dolayı en başından beri ideolojik midir?

4 "Klasik Marksizmde ideoloji genellikle yanlış fikirlerin kapitalist sınıf tarafından üretilip yayılması ve kitlelerde "yanlış bilinçlilik" yaratması olarak anlaşılır" (Kleinhans, 2010, s. 113). 
Bu konudaki kuramsal tartışmaların sinema tarihindeki genel bir görünümünü çıkartan Bonitzer bir tarafa; "[S]inematografik aygit bütünüyle ideolojik bir aygıttır. Doğrudan doğruya Quattrocento'nun bilimsel perspektifinin mirasçısı olan, bu perspektif model alınarak inşa edilmiş bir perspektif kodu üretir" diyenleri koyarken diğer taraftakilerin görüşünü, "[S]inematografik aygıt ideolojik olarak tarafsız bir aygıttır. Doğal göz algısını mekanik olarak yeniden üretir" sözleriyle özetler (2006, s. 115-116). Bu tez ve anti-tez, sinemanın gerçeklikle kurduğu klasik tartışmaları gündeme getiriyor gibi görünse de kameranın, ideolojik olarak manipüle edilmeye ve araçsallaştırılmaya yatkın olduğunu hatırlatması açısından yine de önemlidir. Onu elinde bulunduranlar, dünyayı nasıl görmek ya da göstermek istiyorsa veya (en iyimser yaklaşımla) nasıl görüyorsa, kamera da öyle görür. Böylece sinema, bakışın çoğaltımını ve anonimleşmesini sağlayarak ideolojiye hizmet edebilir. Tabii burada sadece birkaç kişinin görebildiği kişisel kayıtlar ile milyonlarca seyirciyi hedef alan ana akım ticari yapımları ayırmak gerekmektedir. En amatör çekimlerin bile belirli bir ideolojisi vardır. Örneğin sıradan seremoni (düğünler, kutlamalar vb.) videoları, ataerkil düzenle ve aile kurumuyla ilgili egemen normları, garip ritüellerin görselleştirilmesi üzerinden yeniden üretebilir. Ama bunların baskın ideolojinin yeniden üretimine katkısı yine de sınırlıdır. Bu sınırlılığın tek nedeni, bu tür kişisel kayıtların mütevazi bir kitleye hitaben yapılıyor olması değildir. Sürekli kendini belli eden acemi bir kameranın, dramaturjik olarak motive edilmemiş görüntüler üretiyor olması da onların politik etkinliğini zayıflatır. Oysa endüstriyel sistem içerisinde, geleneksel sinemasının anlatısal ve stilistik normlarına göre üretilen filmler böyle değildir. Eleştirel bir bakışın bu tür filmlere şüpheyle yaklaşması ve mesafeli durması için birden çok neden vardır. Bu nedenler en genel şekliyle yapıt içi ve yapıt dışı unsurlar şeklinde şematize edilebilir.

Yapıt dışı etmenlerin başında, filmlerin kapitalist sistem içerisinde ve belirli ekonomik ilişkiler çerçevesinde üretiliyor olması gelmektedir. "Üretim yapıları ve stratejileri metinsel ürünleri güçlü bir şekilde etkiler ve biçimlendirir" (Wayne, 2011, s. 28). Bu da bize tekrar, meta olarak filmlerin de bir ekonomi politiği olduğunu hatırlatır. Onların üretilmeleri için belirli üretim ilişkilerine, sermayeye, pazarlama stratejilerine ve teknolojik alt yapıya ihtiyaç duyulmaktadır ve en muhalif yapımlar bile zorunlu olarak ekonomik döngünün ve eleştirilen sistemin bir parçası haline gelmektedir. Comolli ve Narboni; "[H]er film ekonomik sistemin bir 
unsuru olduğu için aynı zamanda ideolojik sistemin de parçasıdır" (2010, s. 100) derken bunu kastetmektedirler. Sermayeyle olan kaçınılmaz ilişkinin filmleri kitleselleşmeye ve kitleler üzerinde etki uyandırmaya sevk etmesi de yapıt dışı unsurlara dahil edilebilir. Ama filmleri ideolojik açıdan şüpheli halen getiren ve bazı Marksist kuramcıların "histeri" derecesin$\mathrm{de}^{5}$ ona saldırmasına neden olan asıl unsur aracın kendi içinde saklıdır.

Sinemanın kullandığı temsil sistemi, doğal görünüm noktasında figüratif sanatların ya da diğer anlatı platformlarının çok ötesindedir. Film kamerasının da dâhil olduğu optik sistemlerin "bilimsel temelleri kendilerine bir tür 'yansızlık' sağlamakta ve varoluş sebeplerinin sorgulanmasını engellemektedir" (Baudry, 1997, s. 92). Bu bilimsel temeller üzerine oturtulan anlatı ve kurgu retorikleri de hali hazırdaki "yansızlık" yanılsamasını güçlendirmektedir. Bu nedenle filmler, var olan çarpıklıkların doğalcı görünümüne ve bu çarpıklıkların yeniden üretim üzerinden toplumda yerleşikleşmesine diğer tüm sanatlardan daha fazla katkı sağlamaktadır. "Bir ideoloji, gerçeğe benzer görünümlerin bütünü olduğuna göre, sinema yansıttığı ideolojiyi güçlendirmekte, onu bir gerçekmiş gibi ortaya koymaktadır" (Lebel, 1974, s. 31). Hollywood'la özdeşleşen ana akım sinema, kapitalist ekonomiyle kurduğu derin ilişkiler kadar, aracın doğallığa yatkın temsil sistemini biçimsel olarak sömürdüğü için de şüphe uyandırmaktadır. Varolan ekonomik sistemle sıkı bağları olan bir endüstrinin, her şeyi "olduğu gibi" gösterme noktasında mükemmel olan bir aracı, o ekonomik sistemi besleyen toplumsal ve kültürel "üst-yapıya" hizmet edecek şekilde kullandığını düşünmemek için hiçbir neden yok gibidir. "Frankfurt okulunun ana akım sinemayı bir tür narkotik ya da sirk gibi dikkat dağıtıcı olarak" (Kleinhans, 2010, s. 113) itham etmesi, tüm tektipleştiriciliğine rağmen yine de kabul edilebilir durmaktadır. Nitekim ticari sinemanın ele aldığı temalar (bireysel başarı öyküleri, rekabet, milliyetçilik, eril mücadele, savaşın kutsanması vb.) kadar, kullandığı öyküleme ve görselleştirme stratejileri de mevcut düzenin değerlerine çoğunlukla hizmet eder. Ryan ve Kellner bununla ilgili şöyle yazarlar:

Temsil görenekleri, ele alınan konu düzeyinde olduğu kadar biçim düzeyinde de işlerliktedir. Biçimsel görenekler -anlatının kapanma tarzı, görüntünün sürekliliği, dönüşsüz (nonreflexive) kamera işleyişi, karakter özdeşleştirmesi, dikizcilik yoluyla nesnelleştirme, ardışık

5 "Geçmiş düşünüldüğünde 1960'ların ve 1970'lerin Marksist teorilerinden bazıları "devletin ideolojik aygıtları" ve "egemen sinemanın" kötü taraflarını sergilemede bir şekilde abartılı hatta histerik görünürler" (Stam, 2014, s. 149). 
düzenleme, nedensellik mantığı, dramatik güdüleme, kare ortalama, çerçeve uyumu, gerçekçi anlaşılırlık vb.- perdede olup bitenin belli bir görüş açısının ürünü bir kurmaca yapı değil de, nesnel olayların tarafsızca kameraya çekilmiş görüntüleri olduğu yanılsamasını yaratarak ideolojinin yerleşmesine katkıda bulunurlar. Filmler, herhangi bir durumu yansitmaktan çok, o durumun tasarlanan belli bir biçimini oluşturmak üzere seçilmiş ve birleştirilmiş temsili öğeler yoluyla birtakım tezler ileri sürer, bunu yaparken, seyirciye belli bir konumu ya da bakış açısını telkin ederler. Biçimsel görenekler de, sinemasal yapaylığa ilişkin işaretleri silip süpürerek bu konumlamanın içselleştirilmesine katkıda bulunur (2010, s. 17-18).

Bu bakış açısına göre filmlerin biçimini ideolojiden ayrı düşünmek neredeyse olanaksızdır. "Biçim içsel olarak ve doğasında bir ideolojidir" (aktaran Kolker, 1999, s. 145) yargisinda bulunan Fredric Jameson'un ya da Immanuel Kant'ın kavramlaştırmasına yaslanarak "estetik-olan, ideolojik-olandır" (2010, s. 42) diyebilen Eagleton'un genellemeleri sinemaya bu nedenle oldukça uygundur. Çünkü film biçimi de; doğallaştırarak, inandırarak, özdeşleşmeler kurdurarak, belirli bir bakış açısını dayatarak, estetik hale getirerek ve gerçeği manipüle ederek yanlış bilinci canlı tutar. Dikkat edilirse bu eylemlerinin çoğu, göstermek kadar saklamayla da ilgilidir. Çünkü yapıtın kendi üretimini ve oluşum sürecini gizlemesi, anlamı taşıyıcı ve duyguyu oluşturucu diğer araçların işleyebilmesi için de ön şarttır. O nedenle, "ideolojimizin başlıca taşıyıcılarından" (Kolker, 1999, s. 29) olan filmler, bu görevlerini hakkıyla yerine getirebilmek için, tıpkı ideoloji gibi kendi işleyişlerini saklamak zorundadırlar. Dayan bu ilişkiyi şöyle açar:

İdeoloji kendi işleyişlerini gizlemek ve kendi işleyişini ve mesajlarını bir biçimde "doğallaştırmak" zorundadır. Özgül olarak ideoloji üretmeye yönelik sinematografik sistemin gizlenmesi ve filmsel mesajın bu sistemle ilişkisinin saklanması zorunludur. Klasik resimde olduğu gibi, bu kod mesaj tarafından gizlenmelidir. Mesaj kendi içinde tam, tutarlı ve tamamen okunabilir olarak ortaya çıkmalıdır. Bunu yapmak için filmsel mesaj, bu kodun öğeleri çekim-değişimlerini, her şeyden çok bu değişimlerin ardında yatan "bunu kim izliyor?" ve "bu imgeleri kim düzenliyor?" ve "hangi amaçla böyle yapıyorlar?" sorularını gizlemeye çalıştığı için kendi içinde açıklayıcı olmak zorundadır. Bu şekilde izleyicinin dikkati mesajın kendisiyle sınırlanacak ve kod fark edilmeyecektir (2011, s. 88). 
Demek ki filmsel biçimin mevcut değerlere ve egemen düşünceye hizmet edebilmesi için öyküyü ve mesajı ön plana çıkartarak kendini geride tutması gerekmektedir. Çünkü "[S]inemada idealizm, konunun fantazmalaştırılması, aracın gizlenmesine, geriye itilmesine dayanır" (Bonitzer, 2007, s. 19). Bu yüzdendir ki "Amerikan sineması başından itibaren kendini gizlemeye, öykülerinin anlatımını görünmez kılmaya" çalışmıştır (Kolker, 1999, s. 29). Çünkü biçim ne kadar örtükse, onun ideoloji taşıyıcılığı da o kadar işlevseldir. Bu işlevsellik, yeri geldiğinde bir gizleme mekânına da dönüşebilen ekran dışına da çok şey borçludur. Geleneksel anlatılı filmler, üretim süreçlerini ve işleyişlerini saklamak; çerçeve içine verdiği yapay süreklilik hissi ile de inandırıcılıklarını artırmak için buranın görünmezliğinden aktif olarak faydalanmaktadırlar. Bu yönüyle düşünüldüğünde, filmlerdeki kadraj dışı uzay-zamanın ideolojik işleyişe önemli katkılar yaptığı söylenebilir. Eğer "teknik temelin gizlenmesi, su götürmez bir ideolojik etki yaratıyorsa" (Baudry, 1997, s. 93), bu gizlenmeye aracılık eden çerçeve dışını da süreçten ayrı düşünmemek gerekir. Üstelik burası, sadece emeği ve üretimi sakladığı için değil; filmin sahte diegetik uzayına yapay bir devamlllık hissi kattığı için de hegemonik düşüncenin perdedeki yansımasını canlı tutar. Alan dışı aslında, tam da ideolojinin talep ettiği bir büyüye sahiptir: Görünmediği halde imgelerin alımlanışını manipüle eder. Tıpkı ideolojik düşünce gibi, kendini belli etmeden bazı hakikatleri saklar. Ancak saklanan hakikatler bu kez, sınıflı toplumun çarpık yapısına ${ }^{6}$ değil, sinemanın hileli işleyişine dairdir. Yine de bu ikisini birbirinden çok da fazla ayırmamak gerekir. Çünkü filme dair üstü örtülenler, ideolojinin beyaz perdedeki yeniden üretimine de hizmet ederler. Film, görünen ve görünmeyen uzay-zamanlarıyla inandlrıcı olamazsa yanıltıcı içeriğin talep ettiği "doğallık" hissini sağlayamaz.

Ama alan dışının inandırıcılığa katkısı, doğallıkla ve uzamın sahte devamlılığıyla sınırlı değildir. Kendisi görünmediği halde toplumsalı şekillendiren ideoloji, filmlerin görünmeyeninden de farklı şekillerde faydalanabilir. Mesela bir fikir seyirciye doğrudan imgeler üzerinden dayatılmaya çalışıldığında kendini gereğinden fazla açık edebilir. Ama aynı şey, tıpkı atmosferik ses gibi ${ }^{7}$, görünmeyen bir kaynak üzerinden denen-

6 Marksist yoruma göre "bir fikri ideolojik kılan şey, toplumsal ve ekonomik ilişkilerin gerçek doğasını gizlemesi ve böylelikle toplumdaki sosyal ve ekonomik kaynakların eşitsiz dağılımını haklı göstermesi"dir (Mclellan, 2005, s. 15).

7 "Adorno'ya göre, ses film unsurlarını birleştirmeye, yaşamın insan figürü içinde canlanmasına ve kendi açık kendiliğindenliğini onaylatmaya, kendi meka- 
diğinde çok daha iỵi çalışacaktır. Görüntünün fiziksel varlığı inandırmak için yetersiz kaldığında, çerçeve dışı rahatlıkla onun yerini alabilecektir. Çünkü böyle bir inandırıcılığa, sadece doğaüstü güçleri konu edinen yapımlardaki yaratıkların değil, taraflı ve abartılı politik temsillerin de ihtiyacı vardır. Örneğin elinde baltasıyla dolaşarak beyaz adamın kafasını yüzmek için sabırsızlanan "vahşi" Kızılderili temsili bir süre sonra ikna ediciliğini kaybederek ırkçı politik niyeti hemen ortaya çıkarabilir. Bunun farkında olan John Ford Posta Arabası'nda (Stagecoach, 1939), d1şarıda yarattığı Geronimo tehdidini ekrandan uzak tutarak onu sadece öteki haline getirmez; kötücüllüğünü de güçlendirir. Diğer yandan, filmin kahramanı Ringo Kid de (John Wayne) aslında, posta arabasının mürettebatını oluşturan diğer karakterlere sonradan katılır. Ama daha öncesinde üzerine yapılan konuşmalarla görüntüsünden önce öyküye dahil olmuştur; onunla ilgili bazı efsaneler önceden üretilmiş, arkasından da törensel bir çarpıcılıkla olay örgüsüne dahil edilmiştir. Birinde kalıcı diğerinde geçici olan aynı sinematik edim (seyircinin bakışından uzak tutmak), öykü bağlamından dolayı Ringo Kid'i nerdeyse mitsel düzeyde kahramanlaştırırken Geronimo'yu şeytani bir öteki haline getirmiştir.

\section{Gözden Irak, Gönülden Irak}

$\mathrm{Bu}$ klasik örneğin de gösterdiği gibi, temsili kimliklerin alan dışı üzerinden inşa edilmesi, temsilin işaret ettiği kimliğin toplumsal bellekteki yerleşik görünümlerine ve onun diegetik sunumuna göre farklı manipülasyonlara neden olabilmektedir. Ama bunun sadece, sağcı bakışı çok belirgin olan Posta Arabası gibi klasik westernlere özgü olduğunu iddia etmek yanlış olur. Çünkü çoğu sinematik eylem gibi, "dışarıda bırakmak" da özünde ve aslında zaten ideolojik bir girişimdir ve klasik özdeşleşme sinemasının en naif ya da muhalif örneklerinde bile bunun izleri görülebilir. Mesela Küçük Dev Adam (Little Big Man, Arthur Penn, 1970) gibi revizyonist filmlerin "eleştirel temsil stratejisi, Kızılderili yerlilerin bakışını takınmaktan, dolayısıyla ABD askerlerini dışarıdan gelen düşmanlar olarak göstermekten ibarettir" (Ryan \& Kellner, 2010, s. 46). Ylllar sonra Avatar'da da (James Cameron, 2009) görülecek olan bu gibi temsili değiş-tokuşlarda değişen sadece içerideki ile dışarıdakinin, özdeşleşilen ile ötekinin kimlikleridir. Biçimsel sistemin egemen normları ve dışarıda bırakmanın provokatif yanlılığı aynı şekilde işlemeye devam etmektedir.

nik ve aracılık eden yapısını gizlemeye yardım etti" (aktaran Wayne, 2011, s. 9). 
Birileri ya da bir şeyler, öykü evreninin bir parçası olduğu halde gösterilmiyorsa, bunun arkasındaki anlatısal ya da sinematik nedenleri salt öyküye ya da salt biçime indirgemek hata olur. Ana akım bir filmde, karakter kadrajdan çıktıktan sonra kamera da orayı terk ediyorsa ve geride kalanlara ne olduğunu düşünmesi için seyirciye fırsat vermiyorsa bu eylem o kadar da masum değildir. Temel sinematik teknik olarak devamlılık kurgusunu benimseyen bu gelenekteki alışılmış kullanım, oyuncunun sahneyi terk edişinin hemen akabinde diğer sahneye geçiş yapılmasını gerektirir. Üstelik bu yaklaşım, sadece, izlemeyi akışkan hale getirmeye yarayan biçimsel bir eğilimle değil, dünyaya nasıl bakılması gerektiğini dayatan daha kapsayıcı bir tutumla da ilgilidir. Çünkü özdeşleşme odaklı ana akım sinema, ya da politik bağlamıyla söylersek 'Birinci Sinema'8; sadece herhangi bir oyuncunun değil, ana karakterin olmadığ sahnelerin üzerinde bile pek durmaz. Tüm mekanlar ve kadrajlar kahraman odaklıdır ve onunla anlam kazanır. Kazablanka, (Casablanca, Michael Curtiz, 1942), Rambo III (Peter MacDonald, 1988) ya da Argo (Ben Affleck, 2012) benzeri farklı dönemden ya da farklı türden sayısız ana akım Amerikan filminde de görülebileceği gibi, daha önce yabancı olan bir mekân (bu örneklerde Fas, Afganistan ve İran) kahramanla birlikte film kronotopu (uzay-zaman) haline gelir. Büyük oranda Anglosakson olan bu "kahraman" yaban ve öteki topraklardaki görevini tamamlandıktan sonra buralar yeniden öykü evreninin dışına atılır. O nedenle ekran dışı bile sayılmazlar. Kahraman oradan "kurtulmuştur" ve kimsenin kalanlar hakkında düşünmesine gerek yoktur. Genel anlatı düzeyindeki bu "bencil terk ediş", sahneler ve çekimler bazında da geçerlidir. Devamlllık sisteminde kesmeler genellikle harekete yapıldığı için kahramandan önceki ya da sonraki boşluğa pek yer verilmez. O nedenle Yasujirô Ozu'nun, Béla Tarr'ın, Abbas Kiyarüstemi'nin ya da Antonioni'nin ${ }^{9}$ filmlerinde sıklıkla karşımıza çıkan boş odaların ya da caddelerin ana akım sinemada bir karşllı̆̆ı genellikle yoktur.

Bu basit sayılabilecek biçimsel detay aslında, bakış üzerinden özdeşleşmeye ve ötekileştirmeye dair genel bir yaklaşımın ipuçlarını ver-

8 "Birinci Sinema (egemen, anaakım sinema) ve İkinci Sinema (sanat, yönetmen sineması)" (Wayne, 2011a, s. 10) kavramlaştırması genellikle, bir tür politik ve coğrafi kimliği de yansıtan "Üçüncü Sinema" tartışmaları gündeme geldiğinde karşımıza çıkmaktadır.

9 "Antonioni'nin kamerası sık sık sahneyi karakterin ya henüz girmediği ya da henüz terk ettiği durumda tutar (Monaco, 2011, s. 203). 
mesi açısından da önemlidir. Çünkü boş uzam, kendine yakın olanı görmek isteyen ortalama seyirci için en olumsuz durumdur. Bu boşluk ancak bir canlıyla; ama insana yakın bir canlıyla ve mümkünse özdeşleşmenin kolay olabileceği insansı bir canlıyla doldurulursa bir anlam ifade eder. Sinemada özdeşleşme çoğunlukla yüzün görüntüsü üzerinden gider ve bu nedenle sadece bakış özdeşleşmesi (seyircinin bakışının kamerayla ve karakterin bakışıyla özdeşleşmesi) yetersizdir. Yazılı anlatıların aksine sinemada "özne-benin" yüz olduğunu düşünen Bonitzer'e göre, tamamı karakterin bakış açısından çekilen Göldeki Kadın (Lady in the Lake, Robert Montgomery, 1947) gibi yapımlarda yüzün görünmemesi bu nedenle bir bıktırıcılığa neden olur (2006, s. 60). Çünkü seyirci kendisi gibi olanı ya da idealleştirdiği beni perdede görmek ister. Laura Mulvey'in de belirttiği gibi, "skopofiliyi, kendi narsisistik yönü içinde" geliştiren geleneksel sistem "insan yüzü, insan gövdesi, insan bedeniyle çevre arasındaki ilişki, kişinin dünyadaki görünür varlığı" gibi antropomorfik unsurlara özel bir önem verir (2010, s. 216). Bebeğin aynadaki kendi yansımasına bakarak "ben" bilinci geliştirmeye başladığı sürece yarı gerçekçi yarı metaforik bir gönderme yapan "ayna evresi" yaklaşımını sinemadaki seyir deneyimine uyarlayan çalışmalar da genellikle bu mekanizma üzerinde durmuşlardır. Christian Metz, Laura Mulvey ve Jean-Louis Baudry gibi önemli kuramcıların benimsediği bu yaklaşım, sinema çalışmaları açısından da çok daha verimli süreçlerle bağlantılı olan Lacancı "bakış" mefhumunu sadece seyircinin yanlış yönlendirilmiş gözüne indirgediği için şu an kısmen modası geçmiş olsa da ${ }^{10}$, görünüşün ideoloji ve özdeşleşme üzerindeki etkilerini psikanalitik bir temele dayandırdığı için yine de önemlidir. Çünkü bireyin özneleşme sürecindeki önemli bir adımı tanımlayan ayna evresi, kendini tanımayı iki boyutlu bir yüzey üzerindeki imgesel yansıya dayandırdığı için film izleme deneyimini ve filmdeki karakterlerle yakınlaşmayı çağrıştırmaktadır. Ama perde ya da ekran ayna kadar tarafsız ve yansıtıcı olmadığı için film izleme süreci "yanlış tanıma ya da yanlış kavrama (miscognition) edimine" dönüşmekte ve "kişi bir başkasını kendisi olarak tanımakta ya da tersine kendini bir başkasında ve bir başkası olarak (yanlış) algılamaktadır" (Elsaesser \& Hagener, 2014, s. 127). Bu "yanlış tanıma", sinematik imge üzerinden kurulan özdeşleşmenin sorunlu taraflarından sadece biridir. Diğer taraftan, gücünü yıldız oyunculardan, yani idealleştirilmiş "benlerden" alan Hollywo-

10 McGowan, erken dönem Lacancı sinema kuramlarını bu konuda ikna edici bir eleştiriye tabi tutmaktadır (19-23, s. 2012). 
od'un, Bollywood'un ya da benzer başka popüler sinema endüstrilerinin temel silahlarından birini de bu mekanizma oluşturmaktadır. Ayrıca bu sistem, ana akım temsillerdeki sorunlu bir kısır döngünün de en önemli sorumlusudur: Seyircinin görmek istediği yüzler popüler ekranda yeniden sunulur ve onunla olan özdeşlik yeniden onaylanır ve sağlamlaştırılır. Bu güven tazelemenin ters yönünde de işler bir kısır döngü şeklinde işlemeye devam eder. Görülmek istenmeyenler yine dişardadır ve onun ötekiliği ve dışlanmışlığı burada daha da güçlenir. Çünkü gözden uzak olan çoğunlukla gönülden de; yani empati ve özdeşlemeden de uzaktır. Kadrajda çok görünenle özdeşleşmek ne kadar kolay ise, kadrajın dışında kalan da bir o kadar yabancıdır, ötekidir ve hatta öyküsel bağlama göre düşmandır.

Kişinin ayna evresinden beri süregelen "öteki"yle ilişkisi, bir yönüyle kendi kimliğini oluşturmasına yardım ederken diğer taraftan belirli bir savunma mekanizmasını da hayata geçirmektedir. Önceleri yakın çevreden ibaret olan öteki sayısının gün geçtikçe artması ve ilişkilerin karmaşıklaşması, ister istemez böyle bir mekanizmanın gündeme gelmesine neden olmaktadır. Özellikle hakkında az şey bilinenlere karşı tedbiri elden bırakmamak evrimsel denebilecek kadar eski bir alışkanlıktır. Dışarıdaki görünmeyeni bir tehdit gibi algılamanın ve ondan düşmanlar yaratmanın anlatılardaki köklü izleri bu düşünceyi doğrular: "Halk mitolojileri, köyün normal akışının dışındaki ıssız her yere ait aldatıcı ve tehlikeli varlıklarla kaynar. Sözgelimi, Hotantolar çalllıklar ve kumullar arasında rastlanan bir devden bahseder" (2010, s. 95). Joseph Campbell'in bu tespiti akla hemen M. Night Shyamalan'ın KöY (The Village, 2004) ve Emin Alper'in Tepenin Ardl (2012) filmlerini getirir. Birisinde (KöY) dışarıdaki kötülüklerden çocuklarını korumak isteyen büyükler tarafından bilinçli olarak yaratılan ve dramatik akış içerisinde klasik bir gerilim nesnesine dönüştürülen, diğerinde (Tepenin Ardl) ise kırsal yaşamın kapalı yapısından ve düşman yaratma güdüsünün yaygınlığından besleniyormuş gibi duran ${ }^{11}$ "görünmeyen öte ve onun yarattığı tehlikeler" algısı, tıpkı ilkel halk masallarındaki bu paranoyak mantığı çağrıştırır: göremediğimiz dışarı yabandır, yabancıdır, kötücüldür ve tehditlerle doludur.

Halk masallarının ya da bu iki filmin tematik düzeyde başvurdu-

11 Buradaki "gibi duran" ifadesi, Emin Alper'in filminin, "dışarıdaki düşman" fikrinin ulusal kimliğin inşasındaki rolüne ve bunun nefret söylemiyle olan ilişkisine yaptığı alegorik ve zekice atfı ihmal etmemek amacıyla konulmuştur. 
ğu ve özellikle Tepenin Ardı'nın eleştirel bir çözümlemeye tabii tuttuğu ötedeki düşman algısı aslında, birçok filmin anlatısal biçiminin ve dramaturjik işleyiş̧inin temelinde de vardır. Bazı ana akım filmler bir şeyleri tehdit unsuru olarak saklarlar ve onların tehdit gücünü gözden uzakta büyütürler. Bu tehdit, Posta Arabası'nda olduğu gibi başka insanlara tekabül edebilir veya Jaws (Steven Spielberg, 1975) ya da Yaratık'da (Alien, Ridley Scott, 1979) olduğu gibi başka organizmalara gönderme yapabilir. Ama her iki durumda da ötekileştirme ve düşmanlaştırma mekanizması benzerdir. Onların görünmemesi ve dolayısıyla onlarla ilgili enformayonun az olması hep bir tehdit nedenidir. Bu yönüyle düşünüldüğünde sinemanın çerçeve dışı bıraktığı uzay-zaman aslında; Hotanto mitlerindeki çalılıkların, Köy'deki ormanın ya da Tepenin Ardı'ndanki Yörük obasının temsil ettiği şeye denk düşmektedir. Ama burada kastedilen çerçeve dışı, doğal olarak, kameranın bir hareketiyle ya da standart bir devamlılık kesmesiyle hemen görünür hale gelebilecek yakın dış değildir. Anlatısal düzeyde gösterimi ertelenen "ötekilerin düşman bölgesi" uzaktadır ya da ulaşılması emek ister. Onlar görüntü alanına, yani karaktere ve seyirciye yaklaştıkça yarattıkları tehdit de artar.

Bununla ilgili çarpıcı örnekler, 300 Spartalı (300, Zack Snyder, 2006) gibi, savaşı egemen, eril ve tutucu bir bakışla ele alan; onu eleştirmek yerine yücelten ve haklı gösteren ana akım filmlerde bulunabilir. "Cephenin mitleştirilmiş temsil biçimini" (Ryan ve Kellner, 2010, s. 46) kullanan bu tür tek taraflı yapımlarda düşman hattı her zaman yüzü net olarak görülmeyen ya da görülse bile özdeşleşmek için yeteri kadar insancil olmayan "canilerle" doludur. Çünkü onlar hep bilinmeyen öteye aittirler. Diğer taraftan savaşa eleştirel ve mesafeli yaklaşan İnce Kırmızı Hat (The Thin Red Line, Terrence Malick, 1998), Müfreze (Platoon, Oliver Stone, 1986) ve Klyamet (Apocalypse Now, Francis Coppola, 1979) gibi filmler de, ahlaki tutumlarını genellikle cephenin bir tarafındaki karakterler üzerinden sergiledikleri için karşı taraf yine, en iyi ihtimalle, alan dışında ve öteki düzeyinde kalmaktadır. Empati kurmak için gerekli yakınlığın sağlanamaması onların da acı çeken ve duygulanan bireyler olduğu gerçeğini unutturmaktadır. O nedenle topluca katledilmeleri yadırganmadan ve hatta ırkçı yapımlarda bir tür ilkel hazla kabul görmektedir. Mesela sayısı azımsanmayacak Vietnam Savaşı temalı yapımlar, tıpkı westernlerde olduğu gibi, işgalcileri sempatik gösterirken ev sahiplerini de bu yolla kötücülleştirmektedirler. Çerçeve dışında tutularak yaratılan bu düşmanlaştırmanın en temel insani değerlerle bile nasıl 
çeliştiğini özümsemek için, savaş temsillerindeki çarpıklığı yine çerçeve dışı üzerinden irdeleyen duyarlı filmlerdeki ezber bozucu "karşı cephe" temsillerine bakılabilir. Zafer Yolları (Pats of Glory, 1957) ve Dr. Garipaşk (Dr. Strangelove or: How I Learned to Stop Worrying and Love the Bomb, 1964) gibi farklı türlerdeki savaş karşıtı filmleriyle bilinen Stanley Kubrick'in Full Metal Jacket'ı (1987) bunlardan biridir.

Vietnam'da savaşacak olan bir grup deniz piyadesini acemi birliğindeki eğitim sürecinden itibaren takibe alan Full Metal Jacket, anti-militarist tavrını da daha bu aşamada belli eder. Acemi erler, bir taraftan herkesin kaldıramayacağı ve Žižek'in yerinde bir tanımlamayla "askeri özneleri yaratan disiplin prosedürü" (2011, s. 267) dediği sert bir eğitim sürecinden geçerken, diğer taraftan dünyanın öbür ucundaki bir ülkenin insanlarına karşı da nefretle doldurulurlar. En barışçıl olanları bile birer "ölüm makinesine" dönüştüren, cepheye gidildiğinde de azalmayan ve nedeni pek sorgulanmayan bu nefret, filmin dönüm noktasındaki bir çatışma sahnesinde zirveye tırmanır. Sahnenin girişi, Vietnam Savaşını konu edinen tipik filmlerdeki çatışmalar gibi kurgulanmıştır: Terkedilmiş bir binada düşman ya da düşmanlar vardır ve hem karakterlerin hem de seyircinin bakışından uzak olan bu düşman ya da düşmanlar oldukça tehditkardır. Karşıdaki silahlı ve görünmeyen düşmanın gruptaki askerlerden bazılarını yaralaması ona karşı olan öfkeyi de körükler. Mutlaka öldürülmesi konusunda herkesin mutabik olduğu bu "cani" nihayet "hak ettiği" sona ulaşır. Ancak sahnenin bu istenen finali ne seyirci ne de karakterler için beklenen duygusal tatmini sağlamaz. Aksine bu final, herkes için vicdani bir sorgulamaya dönüşür. Çünkü yüzünü göremediğimiz için hep en vahşi haliyle imgelemimizde canlandırdığımız bu düşman aslında neredeyse çocuk yaştaki genç bir kadındır. Kubrick, karşı cepheye yerleştirdiği bu ezber bozucu düşman temsiliyle, önyargllar kadar gözden uzaklığın da beslediği öteki nefretinin nasıl bir şey olduğunu düz ama çarpıcı bir üslupla gözler önüne sermiştir.

\section{Toplumsal Bilinçdışı Olarak Ekran Dışı}

Ötekine dair ön yargılar her zaman göstermeme üzerinden şekillenmez aslında. Aksine, tahayyül edilen ve fantezide inşa edilen "öteki" temsilleri, gösteri sinemasının en fazla ürettiği şeylerden biri olmuştur. Ama bunlar ön yargıların ya da çelişkili egzotik temsil stratejilerinin ${ }^{12}$ şekil- 
lendirdiği stereotiplerin ötesine nadiren geçerler. Afrika'daki, Uzak Asya'daki ya da Güney Amerika'daki insanların gerçek kimlikleri, güncel sorunları ya da sömürgeciliğin buralarda yarattığı tahribatlar, Birinci Sinema'nın ürünlerinde ya öyküye hiç dahil edilmez ya da dahil edilseler bile çoğunlukla alan dışında tutulurlar. Seyircinin kolektif bakışıyla özdeşleşen ticari kamera, çoğunluğun ve egemen ideolojinin görmek istediğini gösterirken görmek istemediğini dışarıda tutarak hem ideolojik hem de ekonomik misyonunu yerine getirir. Üstelik bunu sadece karakter temsillerine değil, tüm bir zaman-uzamsal düzenlenişe ve olay örgüsüne yayarak yapmaktadır. İster insan ister mekân ya da olay olsun her halükârda popüler ekran görmek istenene ev sahipliği yapar. Çünkü gişedeki ekonomik başarı çoğunlukla buna bağlıdır. Örneğin "Spielberg'in filmleri 1980'li yılların mükemmel düşselini, kültürün görmek istediği bütün imgeleri, kültürü tanımlayan imgeler ve anlatıları üreten bir ideolojik üretim fabrikasını oluşturur" (Kolker, 1999, s. 330) ve bu nedenle de genel kitle tarafından tercih edilir. Üstelik Spielberg bunu sadece Kanca (Hook, 1991) ya da Jurassic Park (1993) gibi fantezinin ya da eğlenceli bilim kurgunun hâkim olduğu kaçış filmlerinde yapmaz. Yönetmen, Schindler'in Listesi (Schindler's List, 1993) gibi en gerçekçi filmlerinde bile genel seyirci kitlesini memnun edebilecek imgelere yer verir.

Schindler'in Listesi, tüm belgeselvari görselliğine rağmen estetize edilmiş bir şiddet içerir. ${ }^{13}$ Bu amaçla, kolektif hafızadan güç alan çağrışımsal montajın, belirtisel göstergelerin ve ekran dışı uzamın sunduğu tüm olanaklar sonuna kadar zorlanır. Mesela toplama kamplarındaki vahşet doğrudan gösterilmeden önce krematoryumlardan çıkan duman-

taraftan göstermektir. Aslında söz konusu açmaz, egzotik kelimesinin kökeninden gelmektedir. Alberto Manguel şöyle yazar: "Egzotik kelimesi, Yunanca exotikos kelimesinden gelir. Exotikos "dışarı" anlamındadır, yani şehrin surları içinde olmayan demektir. Yüzyıllar boyunca Avrupalıların nazarında ev ya da "içeride" olan fikri, Batı fikriyle özdeşti. Geriye kalan her şey, "dışarıda" olandı: yabancı, tekinsiz, egzotik, ufkun ötesinde uzanan Doğu. Ortaçağ Avrupası için "dışarıda" olan Afrika'nın ve Asya'nın bir kısmıydı: Koyu tenler ve Etiyopya'daki değerli fildişi, Hindistan'ın zenginliği, Çin'in ritüelleri, Japonya'nın gizemleri, Burma ve Kore'nin bilinmeyen kültürleri, şatafatlı ve gaddar Rus İmparatorluğu, keşfedilmemiş Moğolistan'ın uçsuz bucaksız çölleri. Doğu'dan gelen her şey yabancıydl, diğer bir deyişle, her şey tuhaf ve korkutucu biçimde tenseldi" (2013, s. 44).

13 Yosefa Loshitsky'nin de belirttiği gibi bu belgeselci biçim de aslında, filmin postmodern estetiği içerisinde beliren bir pastişden başka bir şey değildir (1999, s. 362). 
larla önceden mimlenirken, dolaylı gösterimin doğurduğu o garip haz da yine kendini belli eder. Çünkü yönetmen sadece dumanı göstermekle yetinmemiştir. Onun önüne (Oskar Schindler'in [Liam Neeson] arabasının üzerinde birikmiş isi fark etmesi gibi) ve arkasına (histerik ve törensel bir çılgınlığa dönüşen ceset yakma sahneleri) koyduğu çarpıcı görüntülerle süreci anlatısal bir firsata dönüştürmüştür. O nedenle, Spielberg'in böyle bir üslubu tercih ederken, "[F]aşizmin portresini yapmanın imkânsızlığına" inanan ve bunu "[T]ümel esaret görülüp tanınabilir, ama temsil edilemez" sözleriyle gerekçelendiren Theodor Adorno'ya (2000, s. 150) kulak verdiğini iddia edemeyiz. Çünkü Amerikalı yönetmen, faşizmin vahşetini, Amen.'deki (Costa-Gavras, 2002) gibi dolu gidip boş dönen trenlerle ya da Saul'un Oğlu'ndaki (Son of Saul, Nemes László, 2015) gibi bulanıklaştırılmış geri planlarla basitçe ima etmek yerine onu, merak uyandırıcı geciktirimdeki ustalığını sergilediği ve böylece genel kitlenin sevebileceği sinematik bir forma sokmuştur. Kamplardan ara ara verilen sert görüntüler de bu seyir zevkini etkilemez ya da azaltmaz. Çünkü bu görüntüler, toplumun başka filmlerden, belgesellerden ya da o döneme ait haber filmlerinden alıştığı ve kanıksadığı savaş görüntüleriyle çok fazla çelişmez. Aksine, Janusz Kaminski'nin usta sinematografisiyle birleşen Spielberg kurgusu, kanıksanmış bu görüntüleri daha stilize ve izlenesi bir hale sokar. Kamp subayı Amon Goeth'nin (Ralph Fiennes) sadistçe insanları avladığı sahnede de olduğu gibi ara ara "Spielberg bizi bakışın gerçeğiyle karşılaştığımız bir noktaya getirir, fakat ardından bizi kurduğu bir fantazi ekranıyla gerçekten koruyarak ters istikamete dönüş yapar" (McGowan, 2012, s. 236). Film, bu nedenle, bir travmayı hatırlatma ya da bilinçaltındakiyle yüzleşme deneyimine dönüşmez; seyir konforuna düşkün seyircinin tahammül sınırlarını ihlal etmez. "Kan varsa, iş yapar" (Sontag, 2004, s. 18) düsturuyla hareket eden haber medyas1nın şiddeti rutinleştirdiği günümüzde toplama kamplarının aşinalaşmış görüntüleri rahatsız etmekten ziyade anlatısal bir hazza neden olur. Sonuçta savaşa dair rahatsız edecek imgeler (halen) kaldıysa bu, tüm ana akım sinemada olduğu gibi Schindler'in Listesi'nde de içeride değil, dışarıdadır. Savaşa ve kamplara dair onca temsile rağmen filmdeki vahşet, slasher türündeki yapımlarda olduğu gibi bir tür şiddet pornografisine dönüşmez ve bu nedenle de ana akım seyirciyi rahatsız etmez. Çünkü yönetmen, temsilin sınırlarını zorlasa da neyin kabul edilebilir ve neyin kabul edilemez olduğunun farkındadır. O nedenle, Spielberg gibi, seyircisini tanıyan ve onun beklentilerini bilen yönetmenler bir şeyleri gösterip başka bir şeyleri sakllyorsa bunun nedenini Adorno'nun "tümel esaretin 
temsil edilemezliği" ilkesinde değil, toplumsal bilinçaltında aramak daha doğru olacaktır.

Hem üretimindeki kolektiflikten hem de tüketimindeki kitlesellikten dolayı filmlerin ait oldukları toplumun zihniyetini doğrudan yansıttığını düşünen Siegfried Kracauer şunu eklemeyi de ihmal etmez: "Filmler çok açık bir biçimde psikolojik eğilimler olarak amentüleri yansıtmaz - kolektif zihniyetin bu derin katmanları az ya da çok bilinç boyutunun altına uzanırlar" (2010, s. 5-6). Bu görüş, filmlerin bir beyin gibi işlediğini savunan düşünceyle toplumsalın tarafından gelerek kesişir. Çünkü Kracauer'in sözleri, filmlerin, bilinçaltına da sahip olan kolektif bir zihin gibi hareket ettiği şeklinde yorumlanabilir. Ona göre filmler "gizli zihinsel süreçlerle ilgili ipuçları" barındırırlar ve bunlar yakın plan gibi sinematik enstrümanların "neredeyse algılanamaz yüzey bilgisine" ulaştığı yerlerde kendilerini belli ederler (2010, s. 7). Filmler gerçekten de Dişavurumcu Sinemada ve Chaplin'in filmlerinde ${ }^{14}$ olduğu gibi, toplumsal psişenin derinlerinde yatan korkuları, öfkeleri ve arzuları, bir şekilde görünür hale getirmeye çalışabilirler. Ama bir yandan da, tıpkı öznel zihnin baskılama sürecinde yaptığı gibi, bir şeylerin üzerini tamamen örtmek de isteyebilirler. Eğer popüler ekranı toplumsal psikolojinin bir yansıması gibi okuyacaksak, onun farklı nedenlerle görmek istemediği imgeleri de bir şekilde dışarı attığını iddia edebiliriz. "Kadrajın aslında geniş gerçekliği gizlediğini savunanlar da vardır; film-zihin burada muhtemelen bir gizlenme duygusunu düşünüyordur, perdenin dışında kalan bir şeyle bizi huzursuz ediyordur" diyen Daniel Frampton, film-zihin yaklaşımı üzerine konuşurken böyle bir olasılığın varlığını da kabul eder (2013, s. 199). O halde filmleri kamusal bir zihin gibi düşünürsek bu zihnin sakladıkları da, yani çerçeve dışı da, bir yönüyle bir tür toplumsal bilinçdışına tekabül edebilir.

Jacques Rancière'in deyimiyle "evrensel teşhir rejiminin" (2010, s. 79) yürürlükte olduğu ve görsel enformasyonda nerdeyse hiçbir aşırılık sınırının kalmadığı günümüzde, rahatsız edici imgelerden ve bunların baskılanmasından bahsetmek anlamsız gelebilir. Hatta pornografiyle, korku türünün istismar kanadıyla ya da John Waters'ın bayağı ve kiç filmleriyle sinemada bu sinırın sanal platformlardan ve sosyal medya çılgınlığından çok daha önceleri zaten kalkmış olduğunu söyleyebiliriz.

14 "Şarlo'nun bünyesinde had safhada bir toplumsal duygu ve kolektif bilinçaltı iç içe geçmişti" der André Bazin (2011, s. 234). 
Diğer taraftan, "The Code"15 günlerinden kalma alışkanlıkların ve yaş sertifikasyonuyla ilgili baskıların etkisinde olan günümüz kitle filmleri halen bazı görüntülerin üzerini örtme eğilimindedir. Ana akım bir filmin, en fazla seyirciye ulaşabilmesinde anahtar önemde olan "genel izleyici" onayını alması için, hayatın en temel gerçeklerini (ölüm, hastalık, kan, cinsellik, şiddet vb.) görmezden gelmesi ve mevcut kültürel değerlerle uyum içinde olması gerekir. Özellikle çocuk ve aile filmlerinde bu durum çok belirgindir. Bonitzer, "Lumière sineması ölümü görmez"116 derken böyle bir "sinematografik yeryüzü cennetine" gönderme yapar (2006, s. 41). Ama bu, doğal olarak sahte ve aldatıcı bir "cennettir". Dünyaya naif ve masum gözlerle bakıyor gibi görünen filmler (müzikaller, Disney tarzı animasyonlar, romantik komediler, TV güldürüleri vb.) genellikle gerçeklerin üzerinin en belirgin ve acemice örtüldüğü yapımlardır. Bu nedenle de ideolojinin kaba ve görünür haline ev sahipliği yaparlar. Çünkü yaşanan sorunlar ve çatışmalar genellikle birey kaynaklıdır ve iktidar mekanizmaları ya da sınıflı toplum gibi sistemsel, yapısal ya da yaşamsal açmazlar tartışmaya ve çözüme dahil edilmez. Olaylar çoğunlukla savaşın, cinselliğin, ölümün, haksızlığın ve acının olmadığı; iyilerin kazanıp kötülerin kaybettiği bir ütopyada geçiyor gibidir. İçinde bulunulan dünyaya karşı takınılan bu kör tavrın; bu devekuşu politikasının bir çözüm olmadığı bellidir. Çünkü "kaçış" filmleri ve naif yapımlar ne kadar görmezlikten gelse de yaşamın o hakiki yüzü olanca kasvetiyle dışarda beklemektedir.

Buradaki "dışarı" ifadesinin bir parça muğlak durduğu doğrudur. Bu ifade, kadrajın ve olay örgüsünün kapsamadığı zaman-uzama mı yoksa sinema salonunun kapısının dışına mı gönderme yapmaktadır? Pratikte bu ikisi birbirinden farklıdır. Kendisi görünmese de diegetik evrenin bir parçası olan alan dışı aslında ilkiyle ilgilidir. Ama dış dünyanın gerçekliğinden kaçarak perdedeki fantezinin tadını çıkarmak isteyen seyircinin dışarda bırakmak istedikleri ile kadrajın dışarıda bıraktıkları, en azından kaçış filmleri özelinde, bir noktaya kadar birbiriyle örtüşür. Bu tür filmlerde "kâr beklentisi bir tür oto-sansüre" (Metz, 2012, s. 206)

15 Amerikan Film Üreticileri ve Dağıtımcıları Birliği (The Motion Picture Producers and Distributors of America), Katolik cemaati tarafindan da desteklenen "Yapım Kuralları"nı (Production Code) ya da kısa adıyla "The Code"u 1930'da uygulamaya koydu. Filmleri bazı "değerler"e uyulması konusunda zorlayan bu kurallar 1930'dan 1966'a kadar yürürlükte kaldı (Reinhartz, 2007, s. 14-15).

16 İtalik yazım yazara ait. 
neden olduğu için seyircinin dışarı beklentisine mümkün olduğunca sadık kalınır. "Müşterinin" görmek, duymak, karşılaşmak ve yüzleşmek istemediği olaylar ve olgular, gişe gelirinin öncelikli olduğu yapımlarda, öykünün bir parçası olsa bile ekranın dışındadır. O yüzden, ekran dışını toplumsal ve ideolojik bir bağlamda tartışırken bu ikisini keskin bir şekilde birbirinden ayırmamak gerekir. Zaten burada, toplumsal bilinçdışı ile ekran dışı arasında geliştirilmeye çalışılan analoji de böyle bir bütünlük düşüncesinden beslenmektedir. ${ }^{17}$

$\mathrm{Bu}$ analojiye göre, toplumun ve onu oluşturan bireylerin yüzleşmek istemedikleri bazı gerçekler sinemada karşılığını ekran dışında bulmaktadır. Bu gerçekler; izlenilen şeyin bir kurmaca olduğunu açık edecek sinematik unsurlardan, bireysel ve toplumsal geçmişin travmatik olaylarına kadar uzanan geniş bir zemine yayılmaktadır. Baudry gibi, aracın doğasındaki saklamayla ilgilenen kuramcılar sinemayı "egemen ideolojinin belirlediği modele uygun bir tür 'ruhsal vekâlet aracı' olarak" kabul ederken ve "iktisadi alanı kapsayan" bir bastırmadan bahsederken genellikle araçta içkin olarak bulunan gizleyici mekanizmaya gönderme yapmışlardır (1997, s. 98). Buna göre görselleştirme konusunda sınır tanımayan ve güncel sertifikasyonda x-rated olarak bilinen filmler bile, Jean-Luc Godard'ın ya da Dziga Vertov'un yaptığı gibi aracın görünürlüğüne dair bazı müdahaleler de bulunmuyorsa, bu fantazmagorik dışarıda bırakma mekanizmasından muaf değildirler. Diğer taraftan bizim yukarıda bahsettiğimiz "genel izleyici" onaylı kaçış filmleri, bastırmayı ve dışarıda bırakmayı, araca içkin fantazmagoriye yine bağlı kalarak ama bu kez toplumsal, tarihsel ve kültürel dinamiklerden daha yoğun bir şekilde etkilenerek yapmaktadırlar. Sınıflar arası çatışmayı, toplumsal düzendeki çarpıklıkları, norm olarak dayatılanın dışındaki yaşamları, travmaları, toplumun çürümüş yanlarını, gündelik hale gelmiş şiddet türlerini, ait olunan toplumsal bütünün geçmişteki suçlarını ve buna benzer başka

17 Buradaki kullanım, analoji düzeyinde olduğu için Jungcu anlamdaki "kolektif bilinçdışı"yla karıştırılmamalıdır. Çünkü burada, bireye atalarından miras kalmış ve genleriyle aktarılmış biyolojik bir bilinçdışı kastedilmemektedir. Ayrıca Carl Gustav Jung'un tanımladığı "ortak bilinçdışında kişisel hiçbir şey yoktur; bu, en azından bir insan topluluğuna, daha çok bir ulusa, hatta bütün insanlığa aittir" (2006, s. 232). Ama buradaki benzeşimle, birey olarak izleyicilerin ve onun meydana getirdiği izleyiciler kitlesinin, kısmen bilinçli olarak kısmen de Freudyen baskılama mekanizmasına benzer bir bilinçsizlikle dışarıda tuttuğu olayların ve imgelerin filmlerde nasıl karşılık bulduğuna gönderme yapılmak istenmektedir. 
birçok yaşamsal realiteyi görmeyen sayısız ticari kaçış filmi buna örnek gösterilebilir. Ama bunu tipik bir film üzerinden açıklamaya çalışmak oldukça yanlı ve provokatif bir girişim olacaktır. Filmlerin göster(e) medikleri teorik olarak sonsuzluğa tekabül etmektedir ve bu nedenle, herhangi bir gişe filmini kaçış filmi kategorisine sokup arkasından "d1şarıda bıraktıkları" üzerinden onu suçlamak keyfi bir tutumdur. Belki kapsam, neyi gösterebilecekken göstermediği şeklinde daraltılabilir ki; bu kez de "neyi" sorusuna verilebilecek cevapların muğlaklığından dolayı yine abartılı sübjektiflikten kaçılamayacaktır. Kültürel ve ideolojik düzlemden beslenen dışarıda bırakma, henüz konu seçiminden itibaren başladığı için, alan dışı ve eksiltme üzerinden kurulan diegetik dışarı fikri burada tek başına yeterli olamayacaktır ve böylece "neyi" sorusunun cevabı belirsiz kalacaktır. O nedenle konuyla ilgili çözümlemeyi, bu tür filmler yerine, onların göstermediği ve kültürün göz ardı ettiği imgeleri göstermeye çalışan anti-tez ve kod bozucu filmler üzerinden yapmayı denemek daha mantıklıdır.

Bu noktada akla hemen, Birinci Sinema'nın ihmal ettiği coğrafyaları, insanları ve meseleleri ele alan ve politik niyeti bariz olan Üçüncü Sinema gelebilir. Gerçekten de Fernando Ezequiel Solanas, Glauber Rocha ve Souleymane Cissé gibi yönetmenler ylllarca perdeden uzak kalan insanları ve onların sorunlarını görünür hale getirmişlerdir. Ancak bu yönetmenlerin duyarlı filmlerinin politik doğrudanlığı, herhangi bir "bilinçdışı" imge incelemesine olanak tanımamaktadır. Ayrıca, bir tür "dışarıda bırakılan ile yüzleşme" ediminden bahsedilecekse bunu başkası değil, "dışarıda bırakan" zihnin yine ancak kendisi yapabilir. Bu nedenle Birinci Sinema'nın ya da İkinci Sinema'nın kültürel ve toplumsal artalanlı "saklama" günahıyla, yine ancak benzer coğrafyadan çıkan filmler yüzleşebilmektedir.

Bu kapsama girebilecek filmlerden ikisine, Antonioni'nin Tutulma ve Yolcu'suna bu bağlamda yukarıda değinilmişti. Söz konusu eserlerin daha önce ele alınan sekanslarında yönetmen, bariz ve didaktik politik savlar ortaya sürmeden, tam da ekran dışı üzerinden, egemen Batılı bakışla özdeşleştirdiği kameraların gösterme ve saklama normlarıyla toplumsal düşünüssteki saklamanın ve göstermemenin paralelliğine vurgu yapmaktaydı. Ama modernist üslubundan ve anlatısal muğlaklığından taviz vermeyen Antonioni, anlatısını tamamen bunun üzerine kurmak yerine, sadece belirli sahnelerde ve yeri geldiğince konuya değinmekteydi. Daha güncel birkaç örnek ise, belirli türleri ve onların biçimsel norm- 
larını doğrudan yapı bozumuna uğratarak, nerdeyse tüm anlatılarını, gösterilen "fantezi" ile dışarı atılan "gerçek" arasındaki uyuşmazlık üzerine kurmuşlardır. Her ŞeY Yolunda (Tout va Bien, Jean-Luc Godard \& Jean-Pierre Gorin, 1972), Karanllkta Dans (Dancer in the Dark, Lars von Trier, 2000) ve Sitcom (François Ozon, 1998) gibi toplumsal ve politik eleştiriyi sinematik düşünümsellikle birleştiren çoğu eleştirel yapım bu kategoriye dâhil edilebilir. Aynı hatta dahil edebileceğimiz Michael Haneke'nin Saklı'sı (Caché, 2005) ise, bu çözümlemede ekran dışına daha aktif görevler yüklemesiyle de dikkat çeker.

Eleştirisini ve çözümlemesini ekranın sakladıkları üzerinden yapan Saklı, alan dışı ve kolektif bilinçdışı ilişkisi bağlamında daha verimli bir tartışma zemini sunmaktadır. Yönetmeninin öz tanımıyla film, "unutmayı, duyguları bastırmayı ve çocukların "masumiyetini" (Assheuer, 2013 , s. 27) ele almaktadır. Temaya dair yapılan bu sade tanımdaki her bir ifadenin ve hatta işaretin altı yapıtta tatmin edici bir şekilde doldurulur. Unutma, bastırma ve tırnak işaretiyle şüpheli bir hale gelen "masumiyet" kavramları karşılığını sadece öyküde değil, biçimsel tercihlerde de bulur. Orta-üst sınıf Fransız ailesinin "steril" yaşamıyla özdeşleşen filmin temel kamerasının sakladığı ve bastırdığı şeyler, diegetik evren içindeki video kameraların kirli ama dürüst tanıklığıyla tekrar ortaya çıkar. En masum çağımızda bile aslında masum olmadığımıza gönderme yapan tırnak işareti ise esnek olay örgüsünün temel motivasyonunu oluşturur.

Saklı'nın anlatısal temelindeki öykü aslında basit ve standart görünür: Çocukluk çağında bir suç işlenmiştir ve söz konusu suçun zanlısı yetişkinlik çağında bir şekilde bununla yüzleşmek zorunda kalır. Bu yalın öyküyü B sınıfı bir intikam filmi olmaktan uzaklaştırıp Cezayir'deki kolonyal suçların ya da konformist orta sınıftaki yapmacık entelektüelliğin eleştirisine dönüştüren şey ise Haneke'nin konuyu ele alışındaki sert ve eleştirel yaklaşımıdır.

Bir televizyon kanalı için edebiyat programı hazırlayan Georges Laurent'ın (Daniel Auteuil) yaşamı da, neredeyse, stüdyodaki dekoru oluşturan plastik kitaplar ve programın jeneriği akana kadar devam eden gülüşler kadar derinlikten yoksundur. O, sadece bu yabancılaşmış yaşamıyla değil, aynı zamanda sorunlu geçmişiyle yüzleşemediği için de daha büyük bir kitlenin temsilciliğini yapar. Başkalarının suçları gündeme geldiğinde politik doğruculuğun sinırlarını zorlayan "duyarlı" entelektüel, kendi geçmişi söz konusu olduğunda neredeyse körleşmektedir. 
Ne var ki geçmişle bağlantılı olan bazı gelişmeler bu körleşmeyi bozmak üzeredir. Çünkü Laurent ailesi bir süredir gizemli video kasetler almaktadır. Sürekli ekran dışında bekleyen ve hiçbir zaman kim (ya da "ne") olduğunu öğrenemeyeceğimiz gizemli bir kaynak tarafından üretilen ve alelade bir poşette aileye ulaştırılan bu kasetlerin içeriğini başlangıçta, Laurent ailesinin kendi evlerinin görüntüsü oluşturmaktadır. Görüntülerin içeriğinin, ailenin şu an yaşadığı evden Georges'un çocukluğunun geçtiği eve kayması ve kasetlerin yanına iliştirilen acemice çizilmiş ürkütücü bir resim tedirginliğin artmasına neden olur. Kasetleri ve resmi üreten kişi adeta George'a bir ayna tutmaya ve onu geçmişiyle yüzleştirmeye çalışmaktadır. Nitekim böyle de olur ve Georges aynı dönemde çocukluğuyla bağlantılı bazı kabuslar görmeye başlar. Böylece kasetler ile çocukluk çağlarından tanıdığı Majid arasında bağlantı kurar. Majid'in ailesinin 1961'de, Cezayir'deki savaşı proteste etmek amacıyla düzenlenen gösterilerde Fransız polisi tarafından öldürülen yüzlerce kişinin arasında olması öyküyü kolektif geçmişle de bağlantılı hale getirir. Anne ve babası öldürüldükten sonra Georges'in ailesi Majid'i evlat edinmek istemiştir ama o dönemde altı yaşlarında olan Georges bunu engellemiştir. Kasetlerin rehberliğinde Majid'i (Maurice Bénichou) yıllar sonra yeniden bulan ve hem onunla hem de kendi geçmişiyle yüzleşen Georges herhangi bir mahcubiyet duyuyor gibi görünmemektir. Aksine, konforlu yaşamını bir anda "nahoş" bir hale sokan kasetlerden onu sorumlu tutarak saldırganca bir tavır takınır. Bu saldırganlık aynı zamanda, kaçtığı geçmişiyle yüzleşmek zorunda kalmanın verdiği öfkenin de dışavurumu gibidir. Majid boğazını keserek intihar edene kadar da kararttığı bu yaşamın pişmanlığını duyumsamayacaktır.

Temel anlatı düzeyinde bakıldığında Saklı bu şekilde bir yörünge izlese de Haneke'nin aktarım tercihleri filmi, bireysel ve toplumsal olarak bastırdıklarımız üzerine sinematik bir çözümlemeye dönüştürmektedir. Karakterlerin temsilinde metonimi ve alegoriden; bakışın temsilinde ise video kameraların yarattığı çeşitlilikten faydalanan yönetmen böylece, farklı okumalara izin veren çok katmanlı bir yapı kurar. Georges ve Majid'in tekil bireylere tekabül etmemesi gibi video kasetler de aslında barındırdıklarından çok daha fazlasına gönderme yapmaktadırlar. Filmin kendi kamerasıyla çelişerek, dışarıda tutulanın ve gösterilmeyenin gösterilmesine aracılık etmektedirler. Bunu sadece Laurentlar'ın yaşamına ötekinin gözüyle bakarak değil, Majid'in "syhuzet dışı" öyküsüne ışık tutarak da yapmaktadırlar. Özellikle finale doğru ortaya çıkan son 
kaset bunu oldukça çarpıcı bir şekilde ortaya koyarken sadece filmdeki karakterlerin değil, izleyiciler olarak bizlerin de kendi bakışımızı tekrar gözden geçirmemiz gerektiğini hatırlatır.

Söz konusu sahne, dramatik ve politik çatışmanın taraflarını temsil eden iki temel karakterin ylllar sonraki ilk karşılaşmasına aittir. Majid'i kendi evinde (ki metonimik düzlemde Cezayir olarak kodlanabilir) sıkıştırarak ithamlarda bulunan ve neredeyse aşağılayan Georges, sosyo-ekonomik statüsü gereği oldukça yabancı olduğu toplu konutları terk ederken filmin kamerası da onunla birlikte orayı terk eder. Daha önce Hollywood kahramanlık filmleri özelinde bahsettiğimiz "bencil terk ediş" burada da gayet nettir. Filmin "esas oğlanı" ötekilerin yaşadığı gariban semti ${ }^{18}$ terk ettiğinde bizim bakışımız da onunla birlikte oradan ayrılır ve özdeşleşme odaklı seyir alışkanlıklarımız gereği bundan herhangi bir rahatsızlık da duymayız. Böyle bir aşağılamanın ardından orada kalan Majid'in neler yaşadığı çok az kişinin zihnini kurcalar. Bakışımızın ekran dışında bırakılana dair takındığı bu umursamaz tavrın aslında ne kadar gaddarca bir alışkanlık olduğunu, filmin kamerası oradan ayrıldıktan sonra çekim yapmaya devam eden videonun kaydettiği görüntüler ortaya çıktığında anlarız. Videonun "dürüst" tanıklığı da göstermektedir ki, bu ikili konuşmadan sonra takip edilmesi ve kadrajda tutulması gereken kişi Georges değil, konuşmanın asıl mağduru olan ve "biz" oradan ayrıldıktan hemen sonra ağlamaya başlayan Majid'dir.

Haneke, sadece görünen anlatının düzenlenişinde değil, alt anlamların oluşumunda da ekran dışına önemli görevler yüklemiştir. Alımlanan temel anlatı düzeyinde bakıldığında, yoğun eksiltili ve sıçramalı bir yapının tercih edildiği söylenebilir. Ayrıca ailenin konforunu alt üst eden "düşman" da hiçbir zaman tam anlamıyla kadraja girmeden alan dışında bir gizem olarak kalır. Görüntülerin kaynağının finalde de ortaya çıkmayışını saymazsak, bu kullanım klasik gerilimdekine çok benzer. Yoğun eksiltili yapı ise Haneke sinemasında sık rastlanan biçimsel bir motiftir. Ama Saklı'yı ekran dışı uzay-zaman kullanımı noktasında hem Amerikan tarzı klasik gerilimden ve hem de yoğun eksiltili sanat sinemasından ayıran şey, filmin alt metninde de dışarıda bırakılan uzay-zamana önemli anlamlar yüklemesinde yatmaktadır. Haneke kadraj dışını bir taraftan bastırılmışın ve yüzleşilmek istenmeyenin mekânı haline

18 Buraya ulaşan caddenin adının "Lenin" olması da sınıflı topluma yapılan bir gönderme olarak okunabilir. 
getirirken diğer taraftan onu, Libby Saxton'un değimiyle "yeniden haritalandırır" (2007, s. 7). Çünkü bastırma ve dışarıda bırakma sadece filmin karakterlerinin değil, genel itibari ile alışılmış olan egemen bakışın da bir karakteristiğidir. Bu nedenle yönetmen, hepimizin izleme deneyimimizi ve ekran dışı algımızı sorgulatacak bir üslup kullanır. Böylece izlemedeki ikilemi ve seyircinin durumunu da tartışmaya açmış olur (Saxton, 2007, s. 7, 13).

\section{Görünmeyen Muktedir}

Saklı'nın, ekran dışı uzay-zamanı "yeniden haritalandırırken" yaptığı diğer bir şey de gözetleme eyleminin alışılmış taraflarını değiştirmesidir. Film, Yolcu'daki bilge büyücünün yaptığı gibi gözetleyici kamerayı, alegorik düzlemde de olsa, her şeyin olduğu gibi bakışın da hakimi olduğunu düşünen sömürgeci erkin kendine de çevirir. Daha genel bağlamda ise, kendi mahremini gözden uzak tutmaya çalışırken diğerlerini görmek ve gözetlemek isteyen muktedirin durumunu da tartışmaya açar. Böylece konu, kişisel mahremiyetle ilgili olmaktan uzaklaşıp bakış ve iktidar ilişkisine doğru kayar. Çünkü bilgi ve güç arasındaki doğru orantının farkında olan modern iktidarlar, saraylarıyla gövde gösterisi yapmayı ve görünür olmayı seven eski moda ve ilkel erklerin aksine, istediğini istediği zaman gözetlemeyi seçerken kendisi de görünmez olmaya çabalar. Sadece hapishanelerde değil; şehirlerin planlanmasından fabrikalara kadar hayatın her alanında "hiyerarşik hale getirilmiş gözetimlerin" (Foucault, 1992, s. 215) arkasındaki temel dinamiklerden biri de bu bilinçtir. Diğer taraftan böyle bir hiyerarşinin varlığı, gözetleme ve hiyerarşinin doğası gereği, en tepedeki ayrıcalıklının aynı zamanda, en fazla gören ama en az görünen olmasını da gerektirir. Bu durum onun, hem disipliner hem de mitsel gücünü artırır. Disipliner gücünü artırır çünkü denetleme ve kontrol yetisini gözetleme üzerinden elinde tutar. Mitsel gücünü artırır çünkü görünmeyene karşı duyulan korkuyla karışık saygıdan da beslenir. Çünkü "[G]örünmez olanın ideolojisine rıza göstermek" güvenli olmasa da rahatlatıcıdır (Kolker, 2011, s. 165). Bu nedenle bazı anlatılarda da gerçek muktedir, herkesi görürken kendisi genellikle görünmeyen uzay-zamanlarda saklanır.

$\mathrm{Bu}$ anlatılardan ilk akla gelenleri, iktidarın hem evdeki gölgesiyle (baba) ve hem de bürokrasinin ağlarında ya da dilin kurallarında tezahür eden "büyük Öteki" versiyonuyla sorunları olan Franz Kafka'nın yapitlarıdır. Bu yönde verilen en önemli ve en meşhur kavga Dava'da karşılık 
bulsa da, iktidarın görünmezliği ve ulaşılmazlığı konusunda Şato daha yerinde bir örnektir. Haneke tarafından aynı isimle (Das Schloss, 1997) televizyona da uyarlanan eserin olay örgüsü, aldığı yeni iş teklifini takiben Şato'nun kontrolü altındaki köye gelen kadastro memuru K.'nın çevresinde gelişir. Yeni işiyle ilgili bilgi almak isteyen K. bu amaçla, şatoyla bağlantılı yönetici sınıftan birileriyle görüşmek ister. "İktidarın görünmezliği karşısında duyduğu acizlikle K., önündeki kapalı kapıları açma umuduyla beyhude yere birçok kişiyle tanışır" (Cieutat \& Rouyer, 2014, s. 158). Ancak ne şatoya ulaşabilir ne de kontla ve onun yardımcıları olan beylerle görüşebilir. Onların yönetimi altında bulunan mekanlarda, onların emri altında çalışan insanlarla muhatap olsa da iktidarın gerçek sahipleriyle hiçbir zaman yüzleşemez. Tıpkı yönetimin ve gücün sembolü olan şato gibi onlar da görünmezlik derecesinde ulaşılmazdırlar.

Şato'nun meselesi, Ernst Fischer'ın da belirttiği gibi, dönemin Habsburg monarşisiyle ve onun halka yabancılaşmış hantal bürokratik yapılanmasıyla bağlantılı olabilir (1985, s. 36-39). Ama aynı metnin yıllar sonra televizyona uyarlandığında da yadırganmaması ve başka filmlerde de buna benzer görünmez iktidarların olması, en azından otoritenin konumu bağlaminda, konunun o dönemin Prag'ını aşan bir evrensellikte olduğunu da göstermektedir. Hatta gelişen kayıt ve görüntüleme sistemleriyle panoptikonlarını mükemmelleştiren otoritelerin kendi görünmezliklerine daha fazla önem vermeye başladıkları da söylenebilir. Ayrıca somut bir muktedirin (kral, tiran, imparator vb.) olduğu eski sistemlerin aksine, soyut bir "devlet" fikrinin çevresinde şekillenen yeni iktidarlar bu tür bir görünmezliğe daha yatkındırlar. ${ }^{19}$ Bu nedenledir ki, Kafka'nın eserlerindeki, semptomatik (bürokrasi) olarak etkisini gösterirken kendisi görünmeyen erk teması, günümüzün metinsel ve görsel anlatılarında çok daha sık karşımıza çıkmaktadır. Biçimsel yapılandırılmalarını bu doğrultuda şekillendiren bazı filmlerin, otoriteyi bir şekilde öyküye dahil ederken onu hep kadraj dışında tutması, konuyu ekran dışı uzay-zamanın politik boyutuyla da bağlantılı hale getirmektedir.

$\mathrm{Bu}$ konuda örnek gösterilebilecek filmler çeşitlilik gösterdiği için, onları belirli bir sanatsal ya da politik eğilimle gruplandırmak güçtür.

19 "Eski -zalim veya adil, âma her zaman için öldürülmesi serbest- efendinin yerine, bir fikir gibi ölümsüz, bir makine gibi şaşmaz, her ikisi gibi kimliksiz ve de hiçbir şey onu eğip bükemediği, yok edemediği için de, ne yalvarmaların, ne şiddetin erişebildiği Devlet geçti" (Paz, 1993, s. 11). 
Ama Saklı ve Şato dışındaki başka filmlerinde de görünmeyen otoriteye gönderme yapan Avusturyalı yönetmenin bu konuya özel bir ilgi duyduğu söylenebilir. Öyküleri tamamen bunun üzerine kurulmasa da Bilinmeyen Kod (Code Inconnu: Récit Incomplet de Divers Voyages, 2000) ve Tesadüfi Bir Kronolojinin 71 Parçası (71 Fragmente einer Chronologie des Zufalls, 1994) gibi başka Haneke filmlerinde de kadraj dışı otoritelerin örnekleri vardır. Finaldeki trajik bir olayla yolları kesişecek farklı karakterlerin öykülerinden oluşan Tesadüfi Bir Kronolojinin 71 Parçası'nda bu otorite, kendini görmediğimiz halde talimatlarını duyduğumuz bir pinpon antrenörüdür. Bilinmeyen Kod'daki iktidar temsilcisi ise, sadece direktif veren sesiyle kendini hissettiren ve bir zat Haneke tarafından seslendirilen film yönetmenidir. Ses ilk kez provalar sırasında bir video kameranın arkasından duyulduğunda, bir taraftan oyuncu Anne Laurent'i (Juliette Binoche) yönlendirirken diğer taraftan o an sahnede olmayan katilin suflesini de yapmaktadır. Prova edilen sahnenin de kamera önü ve kamera arkası şeklinde tasarlanmış olmasına ek olarak katile ait diyaloğun da sert direktifler içermesi, kurmaca içindeki kurmacanın nerede başladığını ve nerede bittiğini bulanıklaştırmaktadır. Bu bulanıklaştırmanın yarattığı kısmi düşünümsellik, filmin içindeki kurmaca yönetmenle Haneke'nin ve yine kurmaca oyuncu Anne Laurent ile Juliette Binoche'un konumlarını da gözden geçirme fırsatı doğurmaktadır. Haneke bu filmi, Avusturya'da çektiği Tesadüfi Bir Kronolojinin 71 Parçası'nın "Fransa remake'i" (Cieutat \& Rouyer, 2014, s. 255) olarak nitelediği için, antrenör ile film içindeki yönetmeni, etiketleri değişse de toplumsal hiyerarşi içindeki disipline edici işlevleri değişmeyen gündelik figürler olarak değerlendirebiliriz. Yani her iki filmde de yönetmen, film üretim sürecindeki kendi konumunu da sorgulamaya açarak, toplumsal ilişkilerdeki doğallaşmış hegomonik yapıya ve disipline etmeye çalışan bunaltıcı otoritenin gündelik yaşamın kılcallarına kadar işleyen her yerdeliğine, aynı sinematik yöntemleri kullanarak (ekran dışından gelen buyurgan ses) dikkat çekmiştir.

Hayatın her alanına sızan ama kendisi mümkün olduğunca görünmeyen bu otorite figürleri, başka filmlerde genellikle bürokratik hiyerarşi içinde resmedilmektedirler. Devletin bürokratik periferideki en belirgin uzantısını oluşturan mahkemelerdeki "iktidar tecellisi" yargıçlar, bu temsilcilerin en sık rastlananıdır. Öyküde önemli bir yer tutmalarına rağmen kendisi ekran dışında bekleyen yargıç ya da muadili hukuksal mercilere, Raşomon'da (Rashômon, Akira Kurosawa, 1950), 12 Kızgın Adam'da (12 AngrY Men, Sidney Lumet, 1957) ve Bülbülü Öldürmek'te (To 
Kill a Mockingbird, Robert Mulligan, 1962) rastlanabilir. Korkunç Orakçı (La Commare Secca, Bernardo Bertolucci, 1962) ve 9 (Ümit Ünal, 2002) gibi bazı suç merkezli öykülerde ise sorgulayıcı dedektifler ya da polisler görülmezler. Islah evine düşen ergen asi Antoine'a sorular soran psikolog kadının da karşı-alandan konuşması 400 Darbe'yi de (Les quatre cents coups, François Truffaut, 1959) aynı kategoriye dahil edebilir. Kitara'Ya Yolculuk'ta da (Taxidi sta KYthira, Theodoros Angelopulos, 1984) yaşlı devrimci, kendisini hapse atan ve sürgüne gönderen erkle olan hesaplaşmasını, limandaki hapishaneye benzer soğuk ve kasvetli devlet binasındaki psikotik bir sahnede, yukarılardaki görünmeyen güce doğru konuşarak yapar. Detaylı bir tarama yapıldığı takdirde farklı türlerden birçok filmde benzer görünmeyen yargılayıcılar ve sorgulayıcılar bulunabilir. Bu durumun filmlerde bu kadar sık karşılık bulması, tamamen sorgulama pratiğinin alışılmış normlarından (aynalı camın, kameranın ya da ışığın arkasındaki sorgulayıcı klişesi) kaynaklanıyor olabileceği gibi, anlatının dramaturjik yapılanmasıyla da bağlantılı olabilir. Örneğin sınırlandırılmış ve yalıtılmış zaman-mekân içindeki bir grup insanın çatışmasını ele alan 12 Kızgın Adam'da mahkemenin dışarıda tutulması ve tamamen jürinin karar sürecine odaklanılması anlatı biçimine dair tercihlerle ilgili görünmektedir. Ama diğer filmlerin böyle belirgin biçimsel eğilimleri olmamasına rağmen yasa temsilcilerini özenle dışarıda tutmaları ve polis dışı sorgulayıcıların da (gerçek yaşamda böyle olmamasına rağmen) seyirci tarafından görülmemesi, filmlerin uyandırmak istediği duyguyla ya da gönderme yaptıkları alt metinlerle ilgili başka amaçları akla getirmektedir. Söz konusu filmlerin farklı dönemlere ve farklı sinema geleneklerine ait olması uygulamanın amaçlarının çeşitliliğine işaret etmektedir. Ama ekran dişında tutulanın ve böylece kişisizleştirilmeye çalışılanın hep hukuk sistemi içerisindeki yargılayıcılar olması akla ister istemez Kafka'nın "gayri şahsi iktidar aygıtları"nı (Moretti, 2005, s. 230) getirmektedir. Yani Dava'nın ele avuca gelmez, gizemli ve ulaşılmaz yasa koyucusu sinemada karşılığını ekran dışı uzamda buluyor gibidir. Memur K'nın yaşamını kabusa çevirmesine rağmen hiç yüzleşilemeyen yargıç, filmlerdeki söz konusu uygulama için bir prototip gibi değerlendirilebilir. Buna göre, Kafka'nın, "özgür olmamızı engelleyen pozitif toplumsal bir kurumu (devlet bürokrasi gibi), üstesinden gelinemeyecek bir metafizik sınıra çevirmesi" (Žižek, 2014, s. 103) gibi bazı filmler de, doğrudan göstermedikleri yargılayıcı otorite temsilleriyle, kullanılan dilden başlamak üzere yaşamın her yanını saran yasaların soyutluğuna vurgu yapıyor gibidirler. Aynı mantıkla, Dava'da "her zaman yandaki büroda ya 
da kapının ardında, sonsuzda" (Deleuze ve Guattari, 2001, s. 67) bekleyen yasa koyucu bu filmlerde karşıllığını çerçeve dışında buluyor olabilir. ${ }^{20}$

Ama yine de, tüm benzer "yasa erkini göstermeme" uygulamalarını tek bir potada eritip onlara Kafkaesk etiketini yapıştırmak sorunlu bir genelleme olacaktır. Sonuçta hem tema hem de biçim olarak birbirinden farklı olan söz konusu filmler, başka yönleriyle düşünüldüğünde (özellikle de olay örgülerindeki nispi yoğunlukla) Kafka'nın "hiçbir şey olmadığı halde çok şey oluyormuş" gibi görünen psikolojik dünyasından farklıdırlar. Bu nedenle yukarıdaki filmlerin söz konusu sahneleri için başka yorumlar da düşünülebilir. Öyküsel bağlam ve uygulamadaki dikkat çekici vurgular göz önünde bulundurulursa başka amaçlar da fark edilecektir. Örneğin Raşomon'un hem öyküsü hem de hâkimin alan dişındaki konumlanış tarzı (tam kameranın olduğu taraf), yargılama yetkisinin seyirciye devredildiği izlenimi doğurmaktadır. Filmdeki tüm karakterler meşum olayı kendi bakış açılarından ve kendi doğrularıyla anlatırken kesin bir yargıya varmayı engellemektedirler. Yargilanmaları esnasında tüm karakterlerin kompozisyonun tam merkezine konumlandırılmaları ve neredeyse kameraya bakarak ifadelerini vermeleri ise nihai karar merciliğini seyirciye devrediyor gibidir. Filmin, toplumsal bağın çözülmesine dair bir eleştiri barındırdığını öne süren yorum da bunu destekler. Bu yoruma göre, "insanların güvenebileceği bir 'büyük Öteki' yoktur" ve dolayısıyla "güven güvencesini veren ve zorunlulukları destekleyen herhangi temel bir simgesel anlaşmadan" da bahsedilemez (Žižek, 2014, s. 174). Bu durumda neyin doğru olduğuna dair kararı ancak, o öykü evrenine ait olmayan başka bir irade verebilir. Bu bakışa göre, Raşomon'da yargılayıcının karşı-alandaki ekran dışı uzay-zamana alınmasının nedeni yasanın her yerdeliği değil, aksine, hiçbir yerdeliğidir ki bu da Kafkaesk kullanımın neredeyse tam tersidir.

20 Kafka'nın yapıtı ayrıca, ana öyküsü dışında, barındırdığı bazı özel metinlerle de tartışmaya ışık tutabilir. Mesela temel olay örgüsüne bir diyalog vasıtasıyla dahil olan ve "Yasanın Önünde" olarak bilinen kısa bir öykü, yasa ile özne arasındaki karmaşık ve soyut denebilecek ilişkiyi simgeleştirmedeki ve "egemenliğin yapısını örnek bir özetlemeyle" (Agamben, 2013, s. 65) betimlemedeki başarısından dolayı burada da yol gösterici olabilir. Metin, yasanın (kanunun) kapısının önünde ömrünü geçirmesine rağmen bir türlü onun içine giremeyen bir köylüyle ilgilidir. Adam ömrü boyunca sadece en diştaki kapıcıyla muhatap olabilmiştir ve daha ötesine geçememiştir. Ömrünün sonuna doğru kapıcıdan zar zor öğrendiği bir bilgi ise olayı iyice muammalı bir hale sokar. Çünkü zavallı adamın içeriye girmek için ömrünü tükettiği kapı aslında sadece onun için oradadır. 


\section{Sonuç: Kurtarılmış Bir Uzay-Zaman Mümkün mü?}

Yasaya ve kural koyuculara dair batılı ve doğulu bakış arasındaki bu fark, karar verici mercilerin ekran dışı konumlanışlarıyla ilgili kapsayıcı çözümlemeler getirmenin imkansızlığını da göstermektedir. Bunlar arasindaki en önemli ve belki de tek ortak nokta, farklı amaçlarla da olsa, yargılayıcıları ve sorgulayıcıları dışarıda temsil etmeleridir. Biçimi ve göstergebilimi ilgilendiren daha genel bir çerçeveden bakıldığında ise bu kullanım, görünen uzamın temsiliyet yeteneğinin yetersiz kaldığı durumlarda ekran dışının yarattığı belirsizlik ve gizemden yararlanmanın, hukuksal sistemle ya da iktidar temsilleriyle ilgili olan küçük bir ayağını oluşturmaktadır. Yani söz konusu filmler, hareketli görüntünün imgesel dilinin soyut anlamları ve bir tür sonsuzluk düşüncesini üretmek için yetersiz kaldığı yerlerde yoğun bir dışarı vurgusunda bulunan ve peşinde oldukları aşkın düşünceleri görünen uzay-zamanın ötesinde inşa etmeye çalışan Robert Bresson ya da Andrey Tarkovski gibi sinemacıların yaptıklarını daha politik ya da toplumsal bir düzlemde tekrarlamaktadırlar. Ama her iki durumda da mevcut temsil sisteminin dışına çıkmaya dönük bir arzu söz konusudur ve çerçevenin ya da olay örgüsünün ötesine uzanan uzay-zaman bu arzu doğrultusunda araçsallaştırılmıştır.

$\mathrm{Bu}$ durum ekran dışının, gerekirse ve istenirse, mevcut temsil sisteminin, geçerli dil yasalarının ve baskın ideolojik yapılanmaların uzanamadığı bir tür "kurtarılmış alana" dönüşebileceğini de göstermektedir. Yani kadraj dışı uzay-zaman gerektiğinde, "görüntü alanının, görünenlerin ekonomisini düzenleyen dışsal boyutu" (Žižek, 2003, s. 263) olmaktan çıkıp, "gösteren düzeyinde işlediği için her zaman sınırlı" (McGowan, 2012, s. 75) olan ideolojinin ulaşamadığı bir "direniş mekânına" dönüşebilir. Çünkü filmlerin görünen düzlemi, var olan temsil sistemleriyle ve dolayısıyla mevcut ideolojik yapılanmalarla fazlaca hemhal olduğu için Antonin Artaud'nun bahsettiği o "kurtarılmış düşünceye"21 tek başına ulaşamaz. Sinema düşünceyi gerçekten özgürleştirebilecek bir potansiyele sahipse bunu ancak çerçevesinin dışındaki aktif uzay-zamanları da devreye sokarak ortaya çıkarabilir. Bu sayede, belki de, gerçek bir direniş siyaseti için öneminden hep bahsedilen ama bir türlü tam olarak formü-

21 "Artaud sinemayı "düşüncenin yasalarından ve yapılarından kurtulmuş mekanik görüntülerin birbirini izlemesi" olarak tanımlar - Artaud'ya göre sinema imajları insan düşüncesinin ötesine geçmiş, zihnin güçlerini özgürlüğe kavuşturmuştur" (aktaran Frampton, 2013, s. 112). 
le edilemeyen "dışarı düşüncesi"22 sinemadaki karşılığını ekran dışında bulacaktır. Ama burasının böyle bir ihtiyacı karşılaması için de öncelikle, öykü evreninin tamamlayıcılığı şeklindeki klasik misyonundan kurtulup, diegetik işlevlerle yüklenmemiş olan başka bir mekâna dönüşmesi gerekir. Çünkü ekran dışı, bu haliyle, anlatmak için benzer karakterlerin başından geçen benzer öyküler seçen ve sonra bunu geleneksel anlatının "işe yaramıyorsa çıkart" ilkesiyle şekillendiren baskın yaklaşımın retorik bir aracı olmaktan kurtulamayacaktır.

Yukarıda da tartışıldığı gibi bu bakış, dışarıyı sadece içeriyi şekillendirmek ve anlatının dramatik etkisini artırmak için değil, ama aynı zamanda, kültürel ya da ideolojik olarak gösterilmesi uygun olmayanı görüşün dışında tutmak için de araçsallaştırmaktadır. Bu "uygun olmama", bazen basitçe bir kendine benzemeyeni dışlamaya, bazense aleni bir düşmanlaştırmaya işaret eder. Israrla ekran dışının hissedilen ama görünmeyen belirsizliğine hapsedilen öteki, bir taraftan çerçeve içindeki "bize", yani özdeşleşilen temsillere etki edecek kadar yakınken diğer taraftan görme üzerinden kurulacak bir empatiye hep uzaktır. Bu duygunun yarattığı tekinsizlik hissi, ötedeki görünmeyene karşı duyulan düşmanca duyguları daha da güçlendirir. Çünkü uzak dışarıdaki sadece bir yabancıyken, etki edecek kadar yakındaki görünmeyen gerçek bir tehdittir.

Kural koyucu ve denetleyici erk sahibinin görünmemesi de, yine ekran dışının diegetik unsurlara yüklediği bu "uzak ama yakın" ikiliğinden beslenir. Fark, ortaya çıkan duygusal tepkidedir. Ekran dişındaki ve kısmen eş güçteki ötekinin doğurduğu korku daha çok bir düşmanlık yaratırken görünmeyen muktedir korkuyla karışık saygının da nedeni olur.

Ekran dışının ideolojik motivasyonları bağlamında yukarıda yapılan diğer tartışma, temsiliyet meselesiyle ilgili oldukları için kısmen benzerlik gösteren bu iki duruma göre daha farklı bir noktada kaldı. Ötekinin ya da muktedirin dışarıda tutulması bilinçli bir temsil stratejisinin sonucuyken, görülmek ve yüzleşilmek istenmeyen toplumsal ya da yaşamsal gerçeklerin ekran dışına ötelenmesi, en az diğerleri kadar ideolojik olmakla birlikte, daha bilinçsizce yapılan bir edime işaret etmek-

22"Stirner, Foucault, Deleuze ile Guattari ve Derrida, her biri kendi tarzında, bir dışarıya duyulan gereksinimi ima etmişlerdir. Bununla birlikte, onu açıkça formüle edememişlerdir" (Newman, 2006, s. 215). 
tedir. Bu bölümdeki tartışmalardan hareketle, toplumsal kuralların ya da püriten yasaların baskıladığı öznel belleğin ürettiği ama yansıtamadığı gerçeklik imgelerini bilinçaltında depolaması gibi, kitleselliğinden dolayı toplumsal bir bellek işlevi gören televizyon ekranının ya da sinema perdesinin de görülmek istenmeyen şeyleri perdenin ve olay örgüsünün dışına taşıdığı söylenebilir. O nedenle, bu tartışmalardan çıkarılabilecek en temel ve belki de faydalı sonuç, tıpkı konuşma sırasındaki duraklamalarda ve söze dökülemeyen durumlarda hastasının gerçek sorununu yakalayan psikanalist gibi, analizini kitle kültürüne ait ekranların (televizyon ekra$\mathrm{nl}$, sinema perdesi, reklam panosu vb.) göstermeye çekindiği, geçiştirdiği ya da atladığı olgular üzerinden yapan çalışmaların, somut göstergeler üzerinden işleyen klasik çözümlemelere göre toplumsala dair gerçekleri anlamaya çok daha yakın olduğudur.

\section{Kaynakça}

Adorno, T.(2000). Minima Moralia: Sakatlanmış Yaşamdan Yansımalar (Çev. O. Koçak \& A. Doğukan). İstanbul: Metis.

Affleck. B. (Yönetmen). (2012). Operasyon: Argo [Film]. Amerika: Warner.

Agamben, G. (2013). Kutsal İnsan: Egemen İktidar ve Çıplak Hayat (Çev. İ. Türkmen). İstanbul: Ayrıntı.

Alper, E. (Yönetmen). (2012). Tepenin Ardı [Film]. Türkiye: Bulut.

Althusser, L. (1994). İdeoloji ve Devletin İdeolojik Aygitları (Çev. Y. Alp \& M. Özışık). İstanbul: İletişim.

Angelopulos, T. (Yönetmen). (1984). Kitara'ya Yolculuk [Film]. Yunanistan: Greek Film Center.

Antonioni, M. (Yönetmen). (1962). Batan Güneş [Film]. İtalya: Cineriz. Antonioni, M. (Yönetmen). (1966). Cinayeti Gördüm [Film]. İtalya: Premier.

Antonioni, M. (Yönetmen). (1975). Yolcu [Film]. Amerika: MetroGoldwyn-Mayer.

Assheuer, T. (2013). Yakın Plan Haneke (Çev. N. Pakkan). İstanbul: Agora. 
Bakhtin, M. (2001). Karnavaldan Romana (Çev. C. Soydemir). İstanbul: Ayrıntı.

Baudry, J.-L. (1997). Temel Sinematografik Aygitın İdeolojik Etkileri. (Çev. Ç. A. Daldal). Yeni İnsan Yeni Sinema, (2), 92-98.

Bazin, A. (2011). Sinema Nedir? (Çev. İ. Şener). İstanbul: Doruk.

Bertolucci, B. (Yönetmen). (1962). Korkunç Orakçı [Film]. İtalya: Cinematografica Cervi.

Bonitzer, P. (2006). Kör Alan ve Dekadrajlar (Çev. İ. Yaşar). İstanbul: Metis.

Bonitzer, P. (2007). Bakış ve Ses (Çev. İ. Yaşar). İstanbul: Metis.

Burch, N. (1983). Theory of Film Practice (Trans. H. L. Rane), New Jersey: Princeton University.

Cameron, J. (Yönetmen). (2009). Avatar [Film]. Amerika: Twentieth Century Fox.

Campbell, J. (2010). Kahramanın Sonsuz Yolculuğu (Çev. S. Gürses), İstanbul: Kabalc1.

Cieutat, M., \& Rouyer, P. (2014). Haneke Haneke'yi Anlatıyor (Çev. S. İdemen). İstanbul: Everest.

Comolli, J.-L. \& Narboni, J. (2010). Sinema/İdeoloji/Eleştiri (Çev. M. Temiztaş). S. Büker \& G. Topçu (Eds.), Sinema: Tarih-Kuram-Eleştiri (s. 97-108). İstanbul: Kırımızı Kedi.

Coppola, F. F. (Yönetmen). (1979). Kiyamet [Film]. Amerika: Zoetrope.

Costa-Gavras. (Yönetmen). (2002). Amen. [Film]. Fransa: Canal +.

Curtiz, M. (Yönetmen). (1942). Kazablanka [Film]. Amerika: Warner Bros.

Dayan, D. (2011). Klasik Sinemanın Tutor-Kodu (Çev. E. Yılmaz). E. Yllmaz (Ed.), Filmde Yöntem ve Eleştiri (s. 79-93). Ankara: De Ki.

Deleuze, G. \& Guattari, F. (2001). Kafka: Minör Bir Edebiyat İçin (Çev. Ö. Uçkan \& I. Ergüden). İstanbul: Yapı Kredi Yayınları.

Eagleton, T. (1996). İdeoloji (Çev. M. Özcan). İstanbul: Ayrıntı.

Eagleton, T. (2010). Estetiğin İdeolojisi (Çev. B. Gözkân, H. Hünler, T. Armaner, N. Ateş, A. Dost, E. Kılıç, E. Akman, N. Domaniç, A. Çitil ve B. Kıroğlu). İstanbul: Doruk. 
Elsaesser, T. \& Hagener, M. (2014). Film Kuramı: Duyular Yoluyla Bir Giriş (Çev. B. Soner \& B. Yıldırım). Ankara: Dipnot.

Fischer, E. (1985). Franz Kafka. (Çev. A. Cemal). İstanbul: BFS.

Ford, J. (Yönetmen). (1939). Posta Arabası [Film]. Amerika: Walter Wanger.

Foucault, M. (1992). Hapishanenin Doğuşu (Çev. M. A. Kılıçbay). Ankara: İmge.

Frampton, D. (2013). Filmozofi: Sinemayı Yepyeni Bir Tarzda Anlamak İçin Manifesto (Çev. C. Soydemir). İstanbul: Metis.

Godard, J. L. \& Gorin, J. P. (Yönetmen). (1972). Her ŞeY Yolunda [Film]. Fransa: Anouchka.

Haneke, M. (Yönetmen). (2005). Saklı [Film]. Fransa: Les Films du Losange.

Haneka, M. (Yönetmen). (1997). Şato [Film]. Almanya: Wega.

Haneka, M. (Yönetmen). (2000). Bilinmeyen Kod [Film]. Fransa: Arte France Cinéma.

Haneka, M. (Yönetmen). (1994). Tesadüfi Bir Kronolojinin 71 Parçası [Film]. Avusturya: Arte G.E.I.E.

Jung, C. G. (2006). Analitik Psikoloji (Çev. E. Gürol). İstanbul: Payel.

Kleinhans, C. (2010). Marksizm ve Film (Çev. Ö. Yaren). sinecine, 1(2), 109-118.

Kolker, R. (2011). Film, Biçim ve Kültür (Çev. F. Ertınaz, A. Güney, Z. Özen, O. Şakır, B. Tokem, D. Tunalı \& E. Yılmaz). Ankara: De ki.

Kolker, R. P. (1999). Yalnızlık Sineması: Penn, Kubrick, Coppola, Scorsese, Spielberg, Altman (Çev. E. Yllmaz). Ankara: Öteki.

Kracauer, S. (2010). Caligari'den Hitler'e Alman Sinemasının Psikolojik Tarihi (Çev. E. Yllmaz). Ankara: De Ki.

Kubrick, S. (Yönetmen). (1957). Zafer Yolları [Film]. Amerika: Bryna. Kubrick, S. (Yönetmen). (1964). Dr. Garip Aşk [Film]. İngiltere: Columbia.

Kubrick, S. (Yönetmen). (1987). Full Metal Jacket [Film]. İngiltere: Natant.

Kurosawa, A. (Yönetmen). (1950). Raşomon [Film]. Japonya: Daiei. 
László, N. (Yönetmen). (2015). Saul'un Oğlu'ndaki [Film]. Macarista: Laokoon.

Lebel, J.-P. (1974). Sinema ve İdeoloji (Sinema Bilimsel Bir Bulgu mu? İdeolojik Bir Türetim mi?) (Çev. Ç. Y. Boz). Çağdaş Sinema, 1, 30-36.

Loshitsky, Y. (1999). Fantastic Realism: Shindler's List as Docudrama. A. Rosenthal (Ed.), Why Docudrama? Fact-Fiction on Film and TV (s .357-369). Carbondale: SIU Press.

Lumet, S. (Yönetmen). (1957). 12 Kızgın Adam [Film]. Amerika: Orion-Nova.

MacDonald, P. (Yönetmen). (1988). Rambo III [Film]. Amerika: Carolco Pictures

Malick, T. (Yönetmen). (1998). İnce Kırmızı Hat [Film]. Amerika: Fox 2000.

Manguel, A. (2013). Kelimeler Şehri (Çev. E. E. Taş̧̧ığlu). İstanbul: Yapı Kredi.

McGowan, T. (2012). Gerçek Bakış: Lacan Sonrası Sinema Kuramı (Çev. Z. Ö. Barkot). İstanbul: Say.

Mclellan, D. (2005). İdeoloji (Çev. B. Yıldırım). İstanbul: İstanbul Bilgi Üniversitesi.

Metz, C. (2012). Sinemada Anlam Üstüne Denemeler, (Çev. O. Adanır). İstanbul: Hayalperest Yayınevi.

Mitry, J. (1989). Sinema Estetiği ve Psikolojisi (Çev. O. Adanır). İzmir: Dokuz Eylül Üniversitesi Güzel Sanatlar Fakültesi.

Monaco, J. (2011). Bir Film Nasll Okunur: Sinema Dili, Tarihi ve Kuramı (Çev. E. Yılmaz). İstanbul: Oğlak.

Montgomery, R. (Yönetmen). (1947). Göldeki Kadın [Film]. Amerika: MGM.

Moretti, F. (2005). Mucizevi Göstergeler: Edebi Biçimlerin Sosyolojisi Üzerine (Çev. Z. Altok). İstanbul: Metis.

Mulligan, R. (Yönetmen). (1962). Bülbülü Öldürmek [Film]. Amerika: Pakula-Mulligan.

Mulvey, L. (2010). Görsel Haz ve Anlatı Sineması (Çev. N Abisel). S. Büker \& Y. G. Topçu (Ed.), Sinema: Tarih/Kuram/Eleştiri (s. 211-229). İstanbul: Kırmızı Kedi. 
Newman, S. (2006). Bakunin'den Lacan'a Anti-Otoriteryanizm ve İktidarın Altüst Oluşu (Çev. K. Kızıltuğ). İstanbul: Ayrıntı.

Ozon, F. (Yönetmen). (1998). Sitcom [Film]. Fransa: Fidélité.

Paz, O. (1993). Modern İnsan ve Edebiyat (Çev. T. Ilgaz). İstanbul: Remzi.

Penn, A. (Yönetmen). (1970). Küçük Dev Adam [Film]. Amerika: Cinema Center Films.

Rancière, J. (2010). Özgürleşen Seyirci (Çev. E. B. Şaman). İstanbul: Metis.

Reinhartz, A. (2007). Jesus of Hollywood. New York: Oxford University.

Ryan, M. \& Kellner, D. (2010). Politik Kamera: Çağdaş Hollywood Sinemasının İdeolojisi ve Politikası (Çev. E. Özsayar). İstanbul: Ayrintl.

Saxton, L. (2007). Secrets and revelations: Off-screen space in Michael Haneke's Caché. Studies in French Cinema, 7(1), 5-16.

Scott, R. (Yönetmen). (1979). Yaratık [Film]. Amerika: Brandywine.

Shyamalan, M. N. (Yönetmen). (2004). KöY [Film]. Amerika: Touchstone.

Sontag, S. (2004). Başkalarının Acısına Bakmak (Çev. O. Akınhay). İstanbul: Agora.

Snyder, Z. (Yönetmen). (2006). 300 Spartalı [Film]. Amerika:Warner Bros.

Spielberg, S. (Yönetmen). (1975). Jaws [Film]. Amerika: Zanuck/ Brown.

Spielberg, S. (Yönetmen). (1991). Kanca [Film]. Amerika: Amblin.

Spielberg, S. (Yönetmen). (1993). Jurassic Park [Film]. Amerika: Universal.

Spielberg, S. (Yönetmen). (1993). Schindler'in Listesi [Film]. Amerika: Universal.

Stam, R. (2014). Sinema Teorisine Giriş (Çev. S. Salman \& Ç. Asatekin). İstanbul: Ayrintl.

Stone, O. (Yönetmen). (1986). Müfreze [Film]. Amerika: MGM. 
Trier, L. V. (Yönetmen). (2000). Karanlıkta Dans [Film]. Danimarka: Zentropa Entertainments.

Truffaut, F. (Yönetmen). (1959). 400 Darbe [Film]. Fransa: Les Films du Carrosse.

Ünal, Ü. (Yönetmen). (2002). 9 [Film]. Türkiye: PToT.

Wayne, M. (2011). Marksizm, Sinema ve Film İncelemeleri (Çev. E. Yılmaz). M. Wayne (Ed.), Sinemayı Anlamak: Marksist Perspektifler (s. 7-36). Ankara: De Ki.

Wayne, M. (2011a). Politik Film: Üçüncü Sinemanın Diүalektiği (Çev. E. Yllmaz). İstanbul: Yordam.

Žižek, S. (2003, Güz). Bir Vampirizm Kuramı (Çev. Ç. E. Çakmak). Cogito, 37, 262-274.

Žižek, S. (2011). Kırılgan Temas: Slavoj Žižeksten Seçme Yazılar (Çev. B. Somay, T. Birkan \& T. Birkan). İstanbul: Metis.

Žižek, S. (2014). Paralak (Çev. S. Gürses). İstanbul: Encore. 